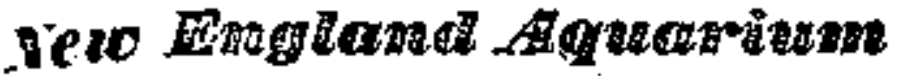

\section{INVESTIGATING THE IMPACT OF DRILLING \\ MUD AND ITS MAJOR COMPONENTS ON \\ BIVALVE SPECIES OF GEORGES BANK}

\section{A Progress Report}

Submitted to:

Department, of Energy

by :

Research Department

New England Aquarium

Cointract No. EE-77-5-02-4580

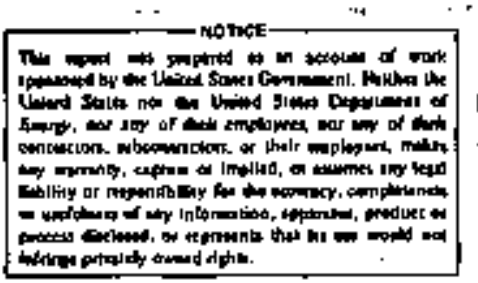

Compel Whan

Eosion. Matoschusptts tielit

Heatere

G. Co Men clead

Director of Research

1 November 1978 


\section{DISCLAIMER}

This report was prepared as an account of work sponsored by an agency of the United States Government. Neither the United States Government nor any agency Thereot, nor any of their employees, makes any warranty, express or implied, or assumes any legal liability or responsibility for the accuracy, completeness, or usefulness of any information, apparatus, product, or process disclosed, or represents that its use would not infringe privately owned rights. Reference herein to any specific commercial product, process, or service by trade name, trademark, manufacturer, or otherwise does not necessarily constitute or imply its endorsement, recommendation, or favoring by the United States Government or any agency thereof. The views and opinions of authors expressed herein do not necessarlly state or reflect those of the United States Government or any agency thereof. 


\section{DISCLAIMER}

Portions of this document may be illegible in electronic image products. Images are produced from the best available original document. 


\section{INTRODUCTION}

The objective of this program has been to measure the responśfe of combercially important marine bivalve molluscs to low levels of drilling muds. Because these materials are composed of several major components whose proportions vary between wells and with depth for a single well, the approach of this study has been to test the major components individually and then to test a "representative" synthetic nud and finally a used drilling mud from an offshore platform. In all but one of these tests the target organism has been the sea scallop, Placopecten magellanicus.

Preliminary range finding experiments were run to determine the ability of sea scallops to tolerate short term exposure to relatively high levels of six components: bentonite, attapulgite, barite, chrome lignosulfonate (CLS), plant starch, and Al stearate. From the results of these tests, dosage Ievels for the 28-day tests of sub-lethal stress were determined.

The following biological and chemical indices have been evaluated as indicators of environmental stress:

1) Visual inspection of selected tissue

2) Filtration rates of test organisms

3) Density and size of mucus cells on the gills and mantle edges

4) Chemical analyses of gills, mantle, fast and slow muscles, digestive gland, and kidney for severaI trace elements.

Since the most chemically active of the major ingredients appears to be CIS, the behavior of this component in sea water 
2

suspensions has been studied and chromium concentrations are . measured in all tissue samples from organisms exposed to cts and to drilling mud mixtures.

During the balance of the first contract period, tests with the synthetic mixtures and with used drilling mud will be run with two other bivalves. Depuration experiments will assess whether these organisms can clear such materials and regain their preexposure appearance and behavior. 


\section{CHARACTERIZATION OF THE DRILLING MUD COMPONENTS}

A. Solubility in sea water

Suspensions of each of the six drilling mud components obtained from Baraid corporation were prepared using filtered Boston Harbor water. Initial tests were carried out at room temperature $\left(20-22^{\circ} \mathrm{C}\right)$. To better simulate the conditions of the Georges Bank enviroment, additional tests were run in isothermal baths at either 10.0 or $15.0^{\circ} \mathrm{C}$ using Harbor water that had been evaporated to give a salinity between 32.2 and 33.0 \% $\%$. Each suspension was stirred for 24 hours before an aliquot was filtered through a $0.45 \mathrm{\mu m}$ porosity membrane.

The results of these tests are presented in Table 1. solubility is expressed in the conventional concentration notation ( $g / L$.$) and also by " insoluble material" because some of$ the components are themselves heterogeneous mixtures of watersoluble and insoluble components. For example, when suspensions of chrome lignosulfonate (CLS) were filtered first through a glass fiber prefilter and then a $0.45 \mathrm{um}$ porosity membrane, the residue on the prefilter was greenish yellow, but the membrane held a much smaller quantity of dark brown material. The results of further characterization of CLS are described below.

\section{B. Quality of the produced water}

Because of the considerable solubility of some of the organic components, their effects on water quality were also assessed. To evaluate immediate oxygen demand, the dissolved 
TABLE 1

SOLUBILITY OF DRIILING MUD COMPONENTS IN SEAWATER

\begin{tabular}{|c|c|c|c|c|c|c|c|}
\hline Component & $\begin{array}{l}\text { Temp. } \\
\left({ }^{\circ} \mathrm{C}\right) \\
\end{array}$ & $\begin{array}{c}\text { Salinity } \\
(0 / 00)\end{array}$ & \multicolumn{2}{|c|}{$\begin{array}{l}\text { Weight of } \\
\text { Component Added } \\
(\mathrm{g} / \mathrm{L})\end{array}$} & \multirow{2}{*}{$\begin{array}{c}\begin{array}{c}\text { Filterable } \\
\text { Solids } \\
(g / \mathrm{h})\end{array} \\
\begin{array}{c}0.0870 \\
0.0706 \\
0.0686\end{array}\end{array}$} & \multirow{2}{*}{$\begin{array}{c}\begin{array}{c}\text { Insoluble } \\
\text { Material } \\
(8)\end{array} \\
\begin{array}{c}1.7 \\
1.1 \\
1.4\end{array}\end{array}$} & \multirow{2}{*}{$\begin{array}{c}\text { Solubility } \\
(\mathrm{g} / \mathrm{L})\end{array}$} \\
\hline $\begin{array}{l}\text { Chrome ligno- } \\
\text { sulfonate }\end{array}$ & $\begin{array}{l}10 \\
15 \\
\mathrm{RT}^{*}\end{array}$ & $\begin{array}{l}32.2 \\
32.2 \\
30.0\end{array}$ & $\begin{array}{l}5.0017 \\
5.0002 \\
4.7688\end{array}$ & - & & & \\
\hline Barite & $\begin{array}{l}10 \\
15 \\
\text { RT }\end{array}$ & $\begin{array}{l}33.0 \\
33.0 \\
30.0\end{array}$ & $\begin{array}{l}1.0007 \\
1.0007 \\
0.9571\end{array}$ & & $\begin{array}{l}0.8268 \\
0.8256 \\
0.8581\end{array}$ & $\begin{array}{l}82.6 \\
82.5 \\
89.7\end{array}$ & $\begin{array}{l}0.17 \\
0.18 \\
0.10\end{array}$ \\
\hline $\begin{array}{l}\text { Aluminum } \\
\text { Stearate }\end{array}$ & $\begin{array}{l}10 \\
15\end{array}$ & $\begin{array}{l}33.0 \\
33.0\end{array}$ & $\begin{array}{l}1.0001 \\
1.0018\end{array}$ & & $\begin{array}{l}0.8334 \\
0.7745\end{array}$ & $\begin{array}{l}83.3 \\
77.3\end{array}$ & $\begin{array}{l}0.17 \\
0.23\end{array}$ \\
\hline $\begin{array}{l}\text { Plant } \\
\text { Starch }\end{array}$ & $\begin{array}{l}10 \\
15 \\
\text { RT }\end{array}$ & $\begin{array}{l}33.0 \\
33.0 \\
30.0\end{array}$ & $\begin{array}{l}1.0003 \\
1.0021 \\
0.9537\end{array}$ & & $\begin{array}{l}0.1270 \\
0.1140 \\
0.0991\end{array}$ & $\begin{array}{l}12.7 \\
12.4 \\
10.4\end{array}$ & $\begin{array}{l}0.87 \\
0.89 \\
0.85\end{array}$ \\
\hline Bentonite & $\begin{array}{l}10 \\
\mathrm{RT}\end{array}$ & $\begin{array}{l}32.2 \\
33.0\end{array}$ & $\begin{array}{l}1.0012 \\
1.0014\end{array}$ & & $\begin{array}{l}0.8462 \\
0.8771\end{array}$ & $\begin{array}{l}84.5 \\
67.6\end{array}$ & $\begin{array}{l}0.16 \\
0.12\end{array}$ \\
\hline Attapulgite & $\begin{array}{l}10 \\
15\end{array}$ & $\begin{array}{l}33.0 \\
33.0\end{array}$ & $\begin{array}{l}1.0004 \\
1.0007\end{array}$ & & $\begin{array}{l}0.9992 \\
0.9340\end{array}$ & $\begin{array}{l}99.9 \\
93.3\end{array}$ & $\begin{array}{r}<0.01 \\
0.06\end{array}$ \\
\hline
\end{tabular}


oxygen (D.0.) concentrations of $1 \mathrm{~g} / \mathrm{L}$ suspensions of the components (5 $\mathrm{g} / \mathrm{L}$ of $\mathrm{CLS}$ ) were measured several times during the first hour of mixing. D.O. levels did not drop more than 0.1 ppm in suspensions of either plant starch or aluminum stearate. The D.O. concentration of the $5 \mathrm{~g} / \mathrm{L}$ suspension of cLs decreased from 6.0 ppm ' 5 minutes after mixing to 5.4 ppm 55 minutes later. The $\mathrm{pH}$ of the CLS suspension was 4.7 while that of Al stearate, at one-fifth the loading was 6.8 or 1.0 unit below the pH of the make-up seawater. While most marine fauna could tolerate the decreases in 0.0 . that were observed, a drop in $\mathrm{pH}$ of one unit or more would likely cause some stress and could prove fatal. The stock suspensions of the acidic components used in the 28-day experiments were neutralized with sodium carbonate before being added to the test tanks.

c. Studies of chrome lignosulfonate Between January and August, 1978, Ms. Fanny Knox, a graduate student in the Department of Interdisciplinary science at MIT, worked at the Aquarium Research laboratory. In her research she attempted to characterize the physical and chemical properties of a commercial CLS, "Q-Broxin" from Baroid corporation, and to study the behavior of seawater suspensions of cLs. The results of this study are contained in his. Knox's M.s. thesis and are summarized in this section. 
1. Physical and chemical properties

Q-Broxin is hyỏroscopic: samples stored in polyethylene bags for several weeks on a laboratory bench lost as of their weight after being dried overnight at $110^{\circ} \mathrm{C}$. After aging at rocm temperature for two hours, the dried samples regained $1 / 4$ of the weight lost on drying.

The average metallic composition of this material is 3\% $\mathrm{Cr}, 28 \mathrm{Fe}, 7 \mathrm{Na}$ and $0.38 \mathrm{Ca} / \mathrm{w}$. The organic content of dried samples was determined indirectly by measuring the loss in weight after heating at $500^{\circ} \mathrm{C}$ for four hours. The ash constituted 25 of the original sample.

Dissolution of Q-Broxin samples always produced a brown solution with a yellow-green residue that was insoluble in distilled or saline water and in polar and non-polar organic solvents. This material made up $1.2 \%$ by weight of dry o-Broxin and contained $58 \mathrm{Cr}, 208 \mathrm{Fe}, 78 \mathrm{Na}$ and $0.88 \mathrm{Ca}$; the ash content was 798. These values were the same for material collected from freshly mixed CLs in water, from a sample aged for three weeks at natural $\mathrm{pH}$ (3.5), and from seawater and distilled water solutions aged $2-8$ days at $\mathrm{pH} 8$. The residue was dissolved in hot concentrated nitric acid and also by treatment with strong base followed by strong ( $\sim 6$ M) acid. The resulting solution from the latter treatment was yellow-green. As its pH was

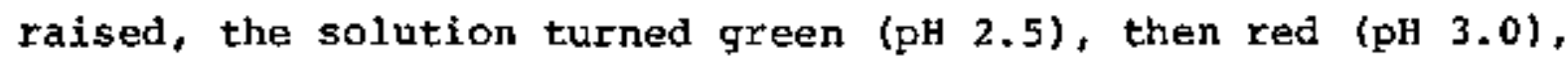
and at pH 6 a reddish-brown precipitate appeared. 
As stated in section A, filtration of CLS suspensions through a glass fiber prefilter and then through a $0.45 \mu \mathrm{m}$ porosity membrane left a brown residue on the latter filter. The amount of filterable brown solid increased in seawater suspensions with aging, but decreased.with time in distilled water suspensions. The material was mostly organic, containing less than $18 \mathrm{Fe}$ and $\mathrm{Cr}$ and may be the product of an aggregation of organic polymers dissolved in media such as seawater where high ionic strength promotes gelling and colloid destabilization.

Q-Broxin is an acidic substance. Titration with base gave an equivalent weight of about 1200 . However, the accuracy of this number is uncertain because of the slow rate at which the $p H$ value of a CIS solution stabilized after the addition of base. The more slowly the titrant was added, the more of the titrant was required to produce a given increase in pll.

A cLs solution stored at pH 8 formed a brown precipitate that contained $3.6 \% \mathrm{Cr}$ and $11.6 \% \mathrm{Fe}$. These results indicate that the $\mathrm{Fe}$ and $\mathrm{Cr}$ in CLS may undergo slow hydrolysis likely involving hydrous oxide polymerization (olation) with the addition of base. Thus, some of the CLS in drilling muds, which are usually made alkaline with $\mathrm{NaOH}$, may be present as lignosulfonate polymers highly cross-linked by the metals or as polymerized chromium and hydrous oxides incorporating lignosulfonate. 
2. Molecular weight distribution

Gel filtration chromatography was used to determine the molecular weight distributions of the fignosulfonate and of the Fe- and Cr-carrying moieties of CLS. Chromatograms typical of those obtained with Sephadex G-100 resin for aged, slightly alkaline solutions and for fresh acidic solutions of CLS are shown in Figures 1 and 2 . Every fifth point on each curve is marked for identification. In both curves, the maxima at fraction number 5 represents material eluting at the column void volume and so corresponds to a molecular size greatex than 0100,000 . The size distribution of aissolved organic matter in the two types of solution may be seen to be similar; however, there are striking differences in metal distributions. Much of the $c r$ and Fe in fresh, untreated czs is associated with low $(<1000-4000)$ molecular weight material. These results are consistent with those described in the previous section and further support the mechanism of slow olation of $\mathrm{Cr}$ and $\mathrm{Fe}$ in CLS solutions.

\section{Interaction with EDTA}

To test the strength and lability of the bonds between Fe and $\mathrm{Cr}$ and the lignosulfonate polymer, excess EDTA was added to freshly prepared and 3-week-old CLS solutions. The pH of the solutions was raised to 8 and then allowed to age 6-9 days before aliquats were eluted through Sephadex G-100. The resulting chromatograms are shown in Figures 3 and 4 . The large maxima at $V_{T}$ indicate that some of the $c x$ and mach of the Fe that would 
FIGURE 1

Chromatogram of a 28 FCLS Solution Aged. for 2 Days at pit. 8

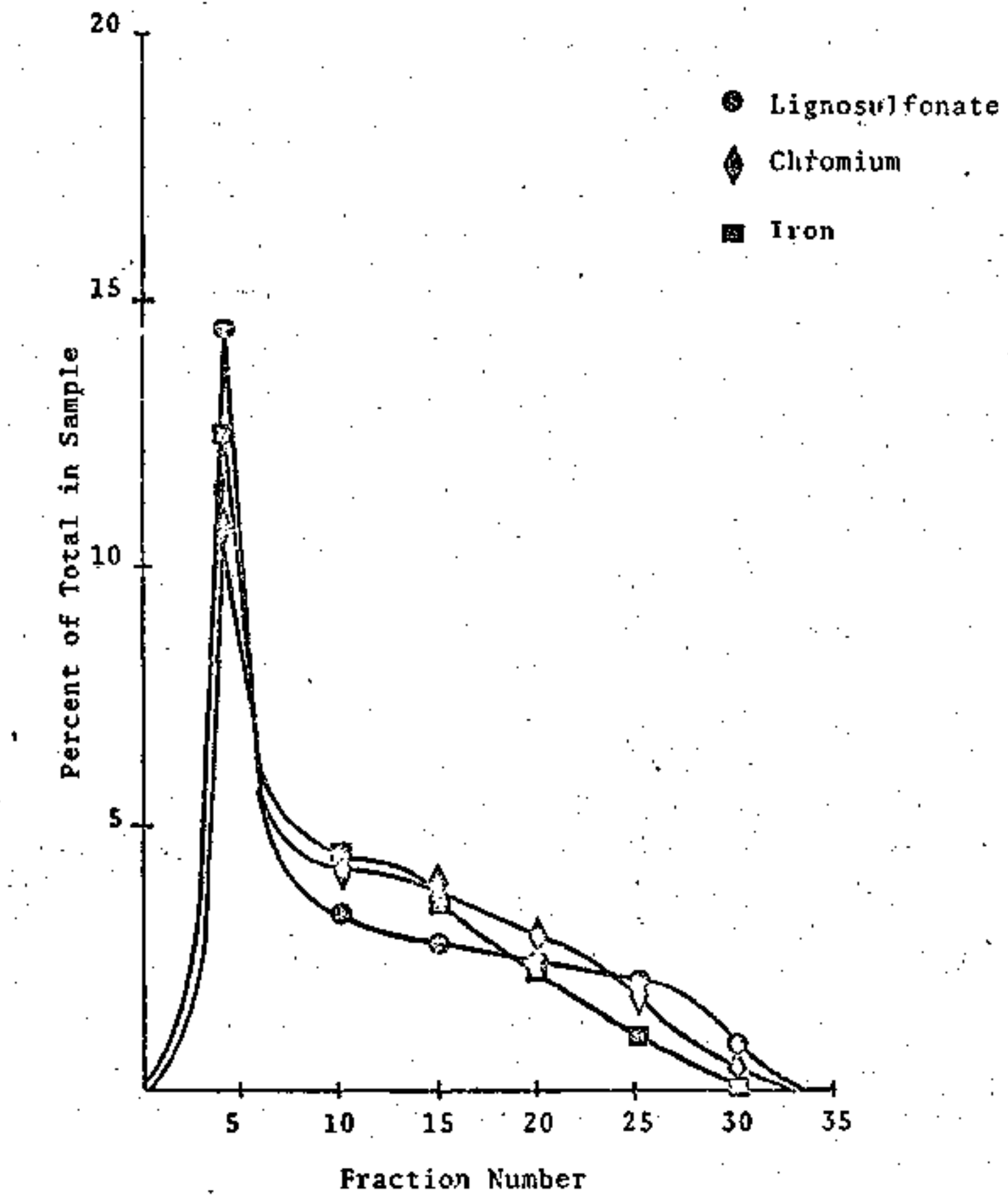




\section{FI GURE 2}

Chromatogram of a $2 \%$ FCLS Solution

$$
\text { Freshly Prepared it } \mathrm{pH} \cdot 4.2
$$

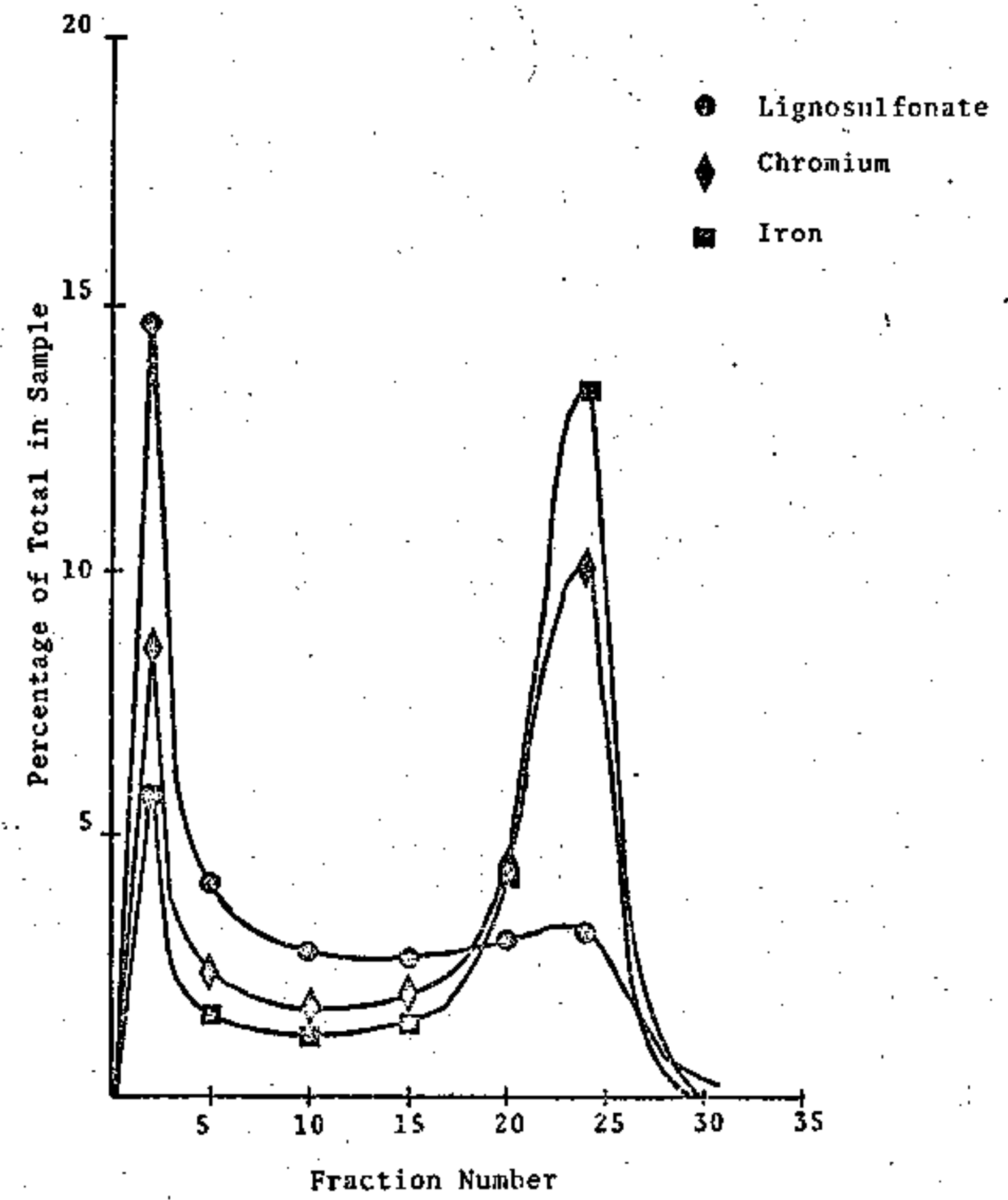


FIGURE 3

Chromatogram of a 2 FCLS Solution

Frestily Prepared; Aged for 6 Days with EDTA

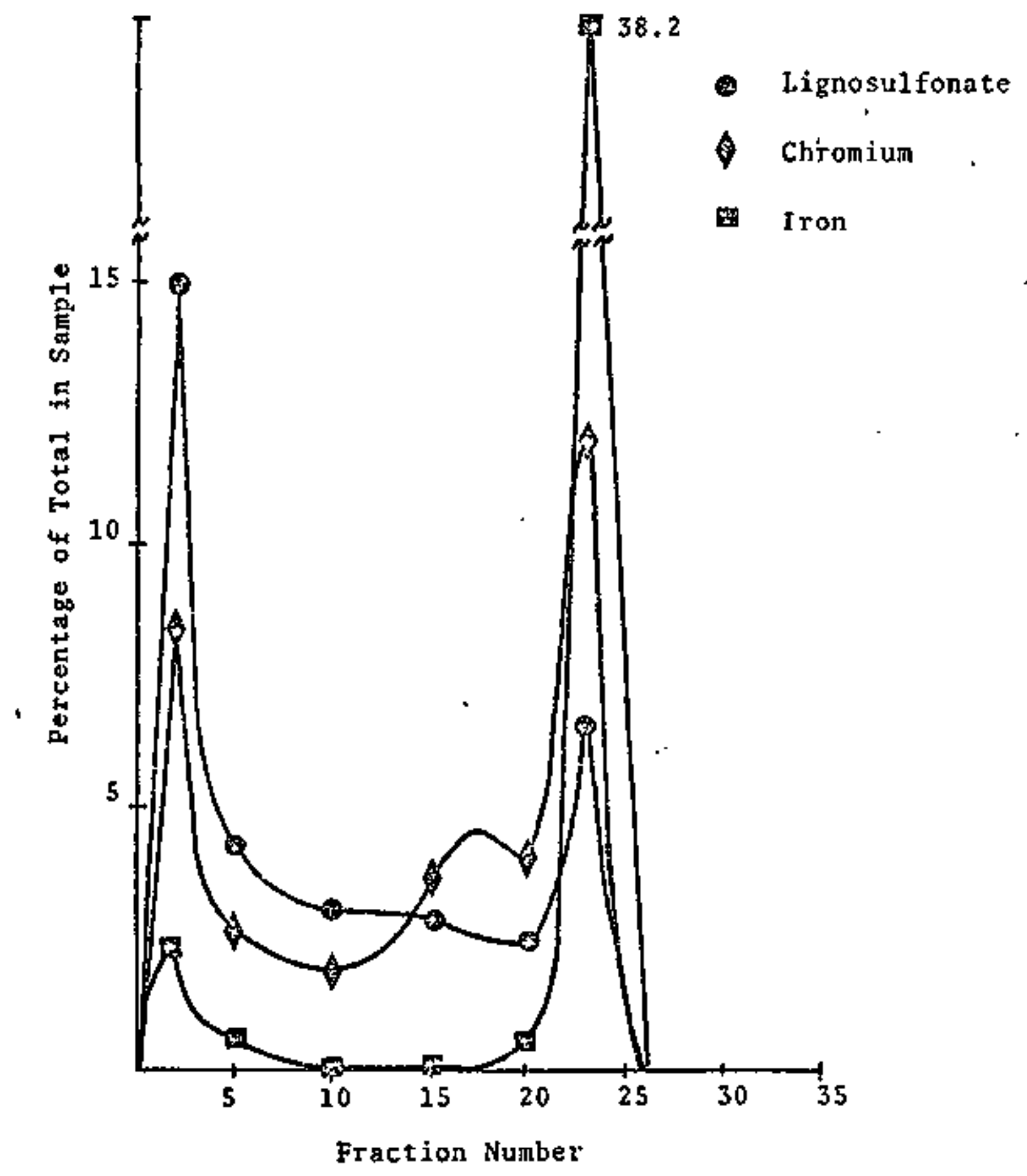


FICURE 4

Chromatogram of a $2 \%$ FCLS Solution

Aged for 3 Weeks; Aged ror 9 Days with EDTA

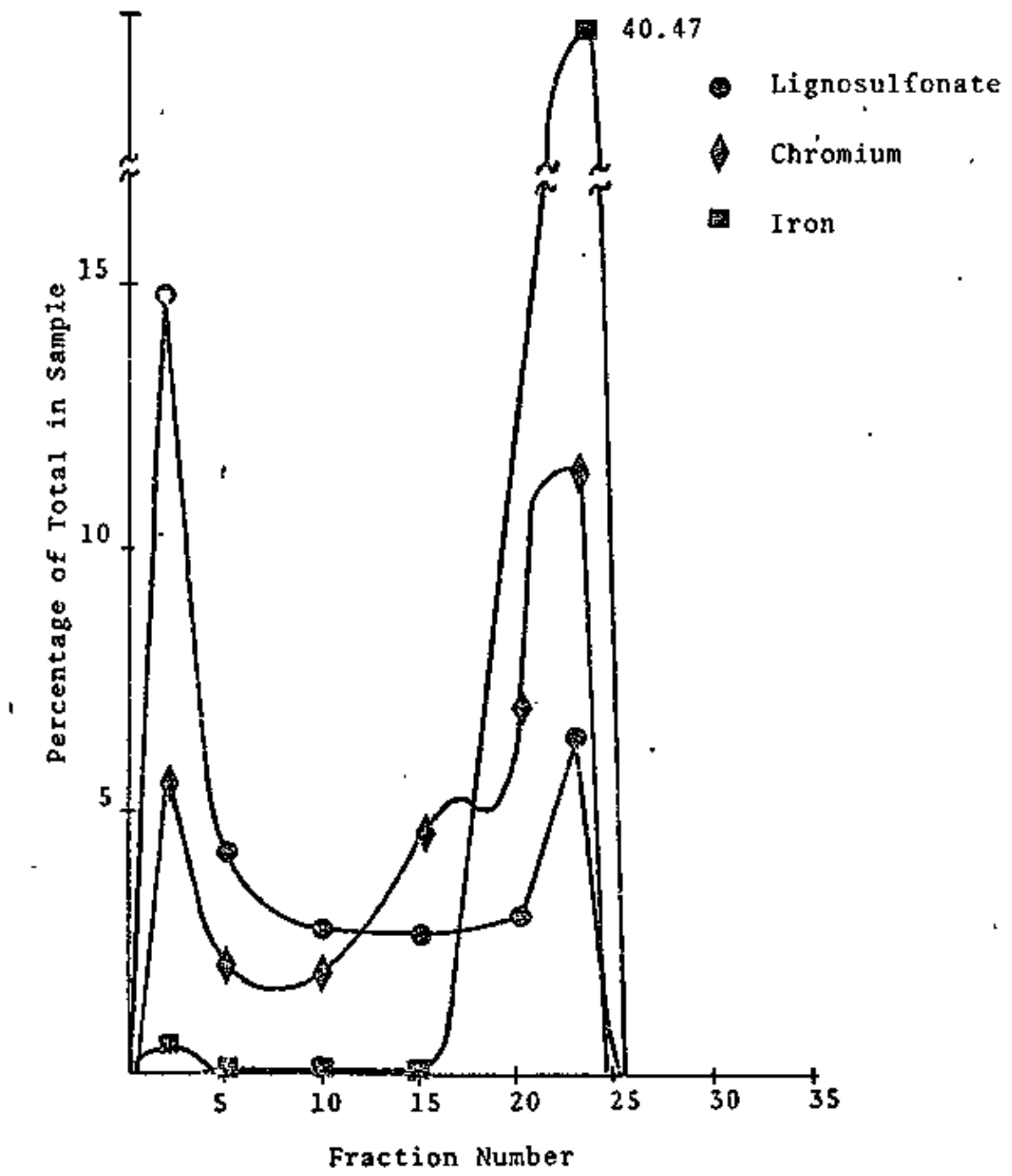


otherwise have been associated with high molecular weight lignosulfonate was present in a low molecular weight matrix, presumably as EDTA compiexes. Less of the.Cr was complexed in the sample aged for three weeks before EDTA was adoed, indicating that the reversal of olation may be a very slow process.

4. Interaction with clay minerals and thermal stability To examine the interaction of CLS with clay minerals, three seawater suspensions containing $0.2 \mathrm{~g} / \mathrm{L}$ Q-Broxin were prepared. One sample also contained $1.0 \mathrm{~g} / \mathrm{L}$ attapulgite, another contained $1.0 \mathrm{~g} / \mathrm{L}$ bentonite, and a third, with no clay added, served as a control. The samples were continuously stirred for 16 days; aliquots were taken periodically, centrifuged, and the dissolved levels of $\mathrm{Cr}$, $\mathrm{Fe}$, and lignosulfonate were measured. The results contained in Table 2 show that attapulgite adsorbs metals and lignosulfonate somewhat more rapidly than bentonite, although the proportion of the metals adsorbed onto the two clays after 16 days was about equal. Since Na and Ca forms of lignosulfonate have been found to be only slightly adsorbed by clays (McAtee and Smith, 1969), the adsorption of cLS is due to the presence of Fe and/or $\mathrm{Cr}$. These results can be accounted for if the $\mathrm{Cr}$ and $\mathrm{Fe}$ adsorbed on the clay also retain some of their lignosulfonate ligands. Since more of the metals than the lignosulfonate are adsorbed, some of the latter may be displaced during the metal adsorption process, or only a fraction of the polymeric units contain $\mathrm{Cr}$ and Fe. 
TABLE 2

COMPOSITION OF SUPERNATANTS OF CLS-CLAY SUSEENSIONS

(8 of Initial Concentrations)

Ligno-
sulfonate

Attapulgite

2 min.

6 hours

1 day

2 days

5 days

9 days

12 days

16 days

Bentonite

2 min.

6 hours

2 days

5 days

9 days

12 days

16 days
89

79

72

70

68

66

64

62

96

90

84

82

76

75

72
Chromium

Iron

75

71

53

41

46

33

38

28

32

23

24

18

23

18

18

36

84

72

71

54

6日

48

55

44

31

30

26

27

14

18 
Since the temperature of the drilling fluid around the drill bit can reach $175^{\circ} \mathrm{C}$, the effects of temperature on the stability of cLs in solution and on the interaction of cLs with attapulgite were examined. Two seawater-based solutions were prepared, one containing $0.2 \mathrm{~g} / \mathrm{L}$ CLS and one containing $1.0 \mathrm{~g} / \mathrm{L}$ attapulgite. The solutions were sampled just after mixing and then brought to boil, which took $30 \mathrm{~min}$, on a combination stirring motor/hot plate. One minute after boiling, a second set of samples was taken, cooled in an ice bath, and then centrifuged. After $15 \mathrm{~min}$. of boiling, a brown precipitate was observed in the CLS solution without clay. After $30 \mathrm{~min}$. of boiling an additional set of samples was taken. The mixtures were allowed to cool, while being stirred, for an additional - hour, when a final subsample was taken.

The results of the analyses of the supernatants are presented in Table 3 . They show that at time $B$, after one minute of boiling but before the onset of precipitation, 508 of the lignosulfonate and over 958 of the $F e$ and $C r$ in CLS were adsorbed on attapulgite. That adsorption occurs much more rapidly at $100^{\circ} \mathrm{C}$ than at room temperature supports the interaction mechanism in which $\mathrm{Cr}$ and $\mathrm{Fe}$ undergo ligand exchange and serve as bridges between the clay lattice and 2 ignosulfonate. 
TABLE 3

COMPOSITION OF SUPERNATANTS OF HEATED SUSPENSTONS

(\% of Initial Concentrations)

Ligno-

sulfonate

Chromium Iron

CLS Only

A

B

C

D

CLs and

Attapulgite
100

100

44

44
93

$90^{\circ}$

2.0

1.1
96

92

1.2

0.3
72
5.7
1. 7 .
1.8
A
82
60
B
50
42
7
4.3
C
42
D

$1.8 \quad 2.0$

1.8

\section{4}

\footnotetext{
A : Just after mixing

B : After l minute of boiling

C: After 30 minutes of boiling

D: After 1 hour of cooling
} 


\section{PRELIMINARY TOXICITY STUDIES}

To evaluate the acute toxicity of the non-clay components of drilling. muds toward sea scallops, short term bioassays were run using the 7 test tanks in the NEA Research Laboratory. Suspensions each containing $1 \mathrm{~g} / \mathrm{L}$ of one of the non-clay components were prepared with filtered sea water. Water temperatures were not closely controlled in these studies; however, room temperature was held between $16-18^{\circ} \mathrm{C}$.

Five organisms were used in each test. To limit the build-up of waste products, the organisms were transferred into fresh test media at 48-hour intervals. No food culture was added to the tanks during testing:

The results of the tests are summarized in Table 4. The data show that the CLS and aluminum stearate suspensions were toxic to more than half the test populations within 24 hours.

However, no deaths were observed in test populations exposed to $0.3 \mathrm{~g} / \mathrm{L}$ suspensions of these two components. 
TABLE 4

RESULTS OF SHORT-TERุH BIOASSAYS WITH PLACOPECTEN MAGELLANICUS

\begin{tabular}{|c|c|c|c|c|c|c|c|}
\hline \multirow{2}{*}{$\begin{array}{l}\text { Date } \\
1 / 10 / 78 \\
1 / 11 \\
1 / 12 \\
1 / 13\end{array}$} & \multirow{2}{*}{$\begin{array}{c}\text { Time of } \\
\text { Exposure } \\
0 \\
0 \\
22 \\
48 \\
72\end{array}$} & \multirow{2}{*}{$\frac{\text { Component }}{\text { CLS }}$} & \multirow{2}{*}{$\begin{array}{l}\begin{array}{l}\text { Initial } \\
\text { Loading } \\
\text { (g/L) }\end{array} \\
1.0\end{array}$} & \multicolumn{2}{|c|}{$\begin{array}{l}\text { Water Temperature } \\
\left({ }^{\circ} \mathrm{C}\right)\end{array}$} & \multicolumn{2}{|c|}{$\begin{array}{l}\text { Cumulative Mortality } \\
\text { (Out of } 5 \text { ) }\end{array}$} \\
\hline & & & & $\begin{array}{r}16.5 \\
15.1 \\
15.5 \\
16.8\end{array}$ & $\begin{array}{l}17.5 \\
16.3 \\
15.5 \\
15.9\end{array}$ & $\begin{array}{l}0 \\
3 \\
3 \\
5\end{array}$ & $\begin{array}{l}0 \\
0 \\
0 \\
0\end{array}$ \\
\hline $\begin{array}{l}1 / 11 \\
1 / 13 \\
1 / 16 \\
1 / 17\end{array}$ & $\begin{array}{r}0 \\
48 \\
120 \\
144\end{array}$ & Cus & 0.3 & $\begin{array}{l}11.5 \\
16.3 \\
16.3 \\
15.8\end{array}$ & $\begin{array}{l}11.5 \\
16.0 \\
16.0 \\
15.5\end{array}$ & $\begin{array}{l}0 \\
0 \\
0 \\
0\end{array}$ & $\begin{array}{l}0 \\
0 \\
0 \\
0\end{array}$ \\
\hline $\begin{array}{l}1 / 10 \\
1 / 11 \\
1 / 12 \\
1 / 13\end{array}$ & $\begin{array}{r}0 \\
24 \\
48 \\
72\end{array}$ & Barite & 1.0 & $\begin{array}{l}17.3 \\
16.3 \\
15.5 \\
.16 .0\end{array}$ & $\begin{array}{l}17.5 \\
16.3 \\
15.5 \\
15.9\end{array}$ & $\begin{array}{l}0 \\
0 \\
0 \\
0\end{array}$ & $\begin{array}{l}0 \\
0 \\
0 \\
0\end{array}$ \\
\hline $\begin{array}{l}1 / 23 \\
1 / 24 \\
1 / 25 \\
1 / 27\end{array}$ & $\begin{array}{r}0 \\
24 \\
48 \\
96\end{array}$ & $\begin{array}{l}\text { Plant } \\
\text { Starch }\end{array}$ & 1.0 & $\begin{array}{l}16.0 \\
15.5 \\
18.5 \\
17.5\end{array}$ & $\begin{array}{l}16.0 \\
15.5 \\
18.5 \\
17.5\end{array}$ & $\begin{array}{l}0 \\
\hat{0} \\
0 \\
1\end{array}$ & $\begin{array}{l}0 \\
0 \\
0 \\
0\end{array}$ \\
\hline $\begin{array}{l}1 / 23 \\
1 / 24\end{array}$ & $\begin{array}{r}0 \\
24\end{array}$ & Al stearate & 1.0 & $\begin{array}{l}16.0 \\
15.5\end{array}$ & $\begin{array}{r}16.0 \\
15.5\end{array}$ & 9 & $\begin{array}{l}0 \\
0\end{array}$ \\
\hline $\begin{array}{l}1 / 30 \\
1 / 31 \\
2 / 1 \\
2 / 3\end{array}$ & $\begin{array}{l}0 \\
24 \\
48 \\
96\end{array}$ & Al Stearate & 0.3 & $\begin{array}{l}16.0 \\
16.0 \\
15.5 \\
15.0\end{array}$ & $\begin{array}{l}16.0 \\
17.0 \\
16.5 \\
15.5\end{array}$ & $\begin{array}{l}0 \\
0 \\
0 \\
0\end{array}$ & $\begin{array}{l}0 \\
0 \\
0 \\
0\end{array}$ \\
\hline
\end{tabular}


IV. METHODS FOR 28-DAY BIOASSAY

(See Table 5)

Deep sea scallops, Placopecten magellanicus, were collected by divers off the Maine coast and transported to the laboratory in insulated coolers chilled with sea water and ice. On axrival, the scallops were placed in running sea water aguaria for one week.

The scallops were acclimated for two days in the test tanks prior to the experiment. A detailed description of the tanks and temperature controls is given in Appendix 1. During accilmation and during the experimental program, scallops were fed a daily ration of the marine flagellate Isochrysis galbana (15 $\mu \mathrm{g}$ chlorophy1l/liter at $15^{\circ} \mathrm{C} ; 1 \mathrm{\mu g}$ chlorophy $1 \mathrm{l} / \mathrm{liter}$ at $5^{\circ} \mathrm{C}$ ). The algae were grown in modified F/2 media (without silicate or metals) uncer cool white fluorescent lights. The test suspension in each tank was changed every two days over the 28-day test period.

During the experiment any dead animals were removed, dissected, and the tissues saved for chemical or histological analysis. At the end of 28 days all scallops were removed, the shells were measured, and the test organisms allocated as follows.

\section{(A) Filtration Rates}

The relative filtration rates were estimated by the neutral red method of Ansell and Sividas (1973). Animals were placed in aguaria containing an 0.003 neutral red solution at 
TABLE 5

SUMHARY OF BIOASSAY METHODS

Collection and maintenance of scallops

$+$

2 day acclimation of scallops in test chambers

28 day experimental period at 4 concentrations of drilling muds

8 scallops per experimental tank

$+\quad$ Removal of dead scallops

Removal of test animals

Filtration experiments

visual observation and recording of tissue condition

$+$

Dissection of gills, mantle, fast and slow muscle, kidney and digestive gland

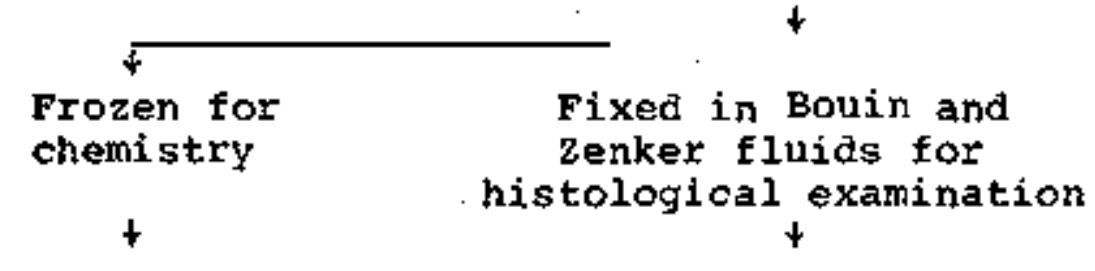

Digestion and analysis for $\mathrm{Cr}$, $\mathrm{Ba}, \mathrm{Sr}$, Cd and $\mathrm{Fe}$ Slicie in gills, mantle, fast and slow muscle, kidney, digestive gland

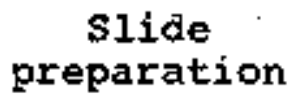


$15^{\circ} \mathrm{C}$. After $2 \mathrm{hr}$, replicate $50 \mathrm{ml}$ samples were taken from each experimental vessel. After acidifying to pH 6.5 with 0.1 N HCl, estimations of concentration were made at $520 \mathrm{~nm}$ in $1 \mathrm{~cm}$ cells in a Spectronic 600 spectrophotometer. The filtration rates were calculated by utilizing the differences between neutral red concentrations in experimental and control aquaria as described by Jorgensen (1943) and Nillensen (1952). The formula used in the present studies was:

$$
m=M \frac{\ln C o-l n C t}{t}-a
$$

where $m$ is the volume of water filtered in liters per hour; $M$ is the volure of the suspension in liters; Co, ct are the concentrations of the filtration medium (either particies or dyes) at the start and end of the experiment; and a is a correction factor derived from control data taken at the start and finish of an experiment, which accounts for changes in the sample beyond those brought about by the experimental organism. Following the filtration experiments, each animal was sacrificed, placed in a tared aluminum dish, dried at $100^{\circ} \mathrm{C}$ for $24 \mathrm{hrs}$, and weighed. These data allowed the expression of the relative filtration rates in relation to dry tissue weight, a less variable parameter than shell-size measurements or live weight determinations, Dry tissue weight also bears a more realistic relationship to the mass of actively metabolizing tissue which the organism must maintain under stressful conditions. Replicate filtration experiments were performed on animals from each exposure regimen. All of the scallops opened their valves and 
formed a mantle veil immediately after being put in the filtration aquaria; they were actively punping: Such activity must be observed at the outset of each experiment, for it must be assumed that the animals are constantly pumping onder to estimate volume relationships -- a constraint of the method. The pumping rates must be considered as relative rates, for it has not been shown that sea scallops remove neutral red from solution at absolute efficiency.

(B) Visual Inspection of Tissues (A11 controls and experimental materials)

Shells were measured and then opened to permit a visual inspection of tissues prior to dissection. The types of observation included clogging of tissues with particulates and the genergl condition of tissues (see Table 2).

(C) Tissue Dissection

Samples of gills, mantle, fast and slow muscle, digestive gland, and kidney were dissected and preserved for chemical and histological analyses.

(D) Chemistry

Tissues for chemistry were frozen and later thawed, digested in boiling nitric and perchloric acids, and analyzed for $\mathrm{Cr}, \mathrm{Ba}, \mathrm{Sr}, \mathrm{Cd}$ and $\mathrm{Fe}$, by plasma emission spectroscopy.

(E) \#istology

The remaining tissues were fixed in Boutn and zenker fluids and embedded in polyester wax. The wax blocks were mounted 
on a mandrel, sectioned on a microtome at 8-10 micrometers and mounted on glass slides without adhesive. The preparations were stained with celestine blue and with alcian blue stain specific for mucopolysaccharides, then dehydrated and mounted. The slides were studied using a compound microscope with $10 \mathrm{x}$ and $40 \mathrm{x}$ objectives.

Five slides were prepared from gill samples of organisms exposed to control and bioassay conditions. Five visual fields were chosen at random from each slide and 20 contiguous gill filament cross-sections were identified in each field, for a total of 125 cross-sections per slide. Each filament crosssection in a field was divided by classical anatomical landmarks into frontal, latero-frontal, lateral, and abfrontal areas. The presence of mucus goblet cells, stained with alcian blue stain, in each of the four areas of each crosssection was separately noted and enumerated. The observations per slide were made, therefore, according to the matrix: experimental conditions $\times 5$ fields $\times 25$ cross sections $x 4$ anatomical areas $=500$ observations per slide.

Table 6 summarizes the experimental protocols of experiments from November 1977 through september 1978. The first three experiments tested the clay components of drilling muds -- attapulgite and bentonite -- at four concentrations and two temperatures. Experiments 4 and 5 tested chrome lignosulfonate and barjum sulfate at four concentrations and two temperatures. 
TABLE 6

SUMMARY OF EXPERIMENTAL PROTOCOL

\section{Expt. Date}

19 Nov. 77-

7 Dec. 77

$220 \mathrm{Jan}, 78-$

6 Feb. 78

320 Feb. 78 -

20 Mar. 78

4. . 27 Mar. 78-

26 Apr. 78

$5 \quad 12$ May 78-

9 Jun. 78

629 Jun. 78-

28 Jul. 78

7 B Aug. 78-

a Sep. 78

828 Sep. $78-$ 26 Oct. 78

\section{Material \& Concentration (ppt)}

Attapulgite

$3.0,1.0,0.3,0.1$

Attapulgite

$3.0,1.0, .3, .1$

Attapulgite

$3.0,1,0, .3, \ldots 1$

chrome

Lignosulfonate

$1.0,0.3,0.1,0.03$

Chrome

Lignosulfonate

$1.0,0.3,0.1,0.03$

Combined mudAttapulgite

$3.0,1.0, .3, .1$

Combined mudAttapulgite $3.0,1.0,: 3, .1$

Combined mudAttapulgite $3.0,1.0, .3, .1$
Bentonite

$3,0,1,0,0,3,0,1$

Bentơnite

$3.0,1.0, .3, .1$

Bentonite

$3,0,1.0, \ldots 3, .1$

Barium sulfate

$3,1,0,3,0.1$

Barium sulfate

$3,1,0.3,0.1$

Combined mud-

Bentonite

$3.0,1.0, .3, .1$

Combined mudBentonite

$3.0,1.0, .3, .1$

Combined mua-

Bentonite

$3,0,1,0, .3, .1$. $15^{\circ}$

Temp. $\left({ }^{\circ} \mathrm{C}\right)$

$15^{\circ}$

$5^{\circ}$

$5^{\circ}$

$5^{\circ}$

$15^{\circ}$

$5^{\circ}$

$15^{\circ}$

\section{Organism}

Placopecten mage I Ianicus

Placopecten magelianicus

\section{Placopecten} magellanicus

Placopecten magellanicus

Placopecten magellanicus.

Placopecten mage Ilanicus

Placopecten magellanicus

Spisula solidissima 
Aluminum stearate and plant starch were not tested individually; rather, these ingredients were added to mixtures of the major components. While seawater-based muds often contain alumintm stearate as a defoamer and plant starch to reduce fluid losses and to keep barite in suspension, these materials usually constitute only 0.1-0.3\% of the total mud weight.

Based on some typical mud compositions contained in parts of an offshore drilling draft E.I.S. given us by Dr. Bruce Coons of A.P.I., the following weight ratios seemed appropriate.

$\begin{array}{lr}\text { Baso }_{4} & 1.50 \text { parts } \\ \text { Clay } & 1.00 \\ \text { Chrome ligno- } & \\ \text { sulfonate } & 0.20 \\ \text { Al Stearate } & .01 \\ \text { Plant Starch } & .01\end{array}$

Translating these values directly into $G / L$ gave a total loading of $2.7 \mathrm{~g} / \mathrm{L}$, or about the maximum employed for any one component in the earlier tests. Diluting this loading by factors of 3,10 and 30 produced the usual 4-concentration experimental matrix. Attapulgite was used in one series and bentonite in the other. 


\section{RESULTS OF 28-DAY BIOASSAYS}

\section{A. Mortality}

Dead scallops were removed from the tanks dajly and a record kept of date of removal. Tables 7 through 13 sumarize this data. Records of the mortality of test scallops during the first 10 days of the experiment (Tables 14-16) clearly show the effects of higher temperature at the high concentrations of mud components.

\section{B. Visual Inspection of Tissues}

The results of a visual inspection of tissues is sumprarized for experiments 6 and 7 (the synthetic muds with attapulgite or bentonite) in Tables 17-20. The observations fall into four categories: 1) disattachnent of muscle and mantle from she11; 2) response of muscles to a probe;
3) presence of
of clay in
in mantle and gill;
4) condition of kidney.

Although the data are the results of subjective observation and the samples are small, stress is clearly evident in organisms exposed to the attapulgite-based synthetic muds at. concentrations of 3.0 and $1.0 \mathrm{~g} / \mathrm{L}$ and is present to a lesser degree at $0.3 \mathrm{~g} / \mathrm{L}$. The condition of scallops exposed to a concentration of $0.1 \mathrm{~g} / \mathrm{L}$ is similar to that of the controls. In scallops exposed to combined muds and bentonite, similar effects are observed at the same concentration ranges, and clogging with clay was seen even at the lowest mud concentration. 
TABLE 7

MORTALITY IN EXPERIMENT \# 1

( $/ B$ in each tank)

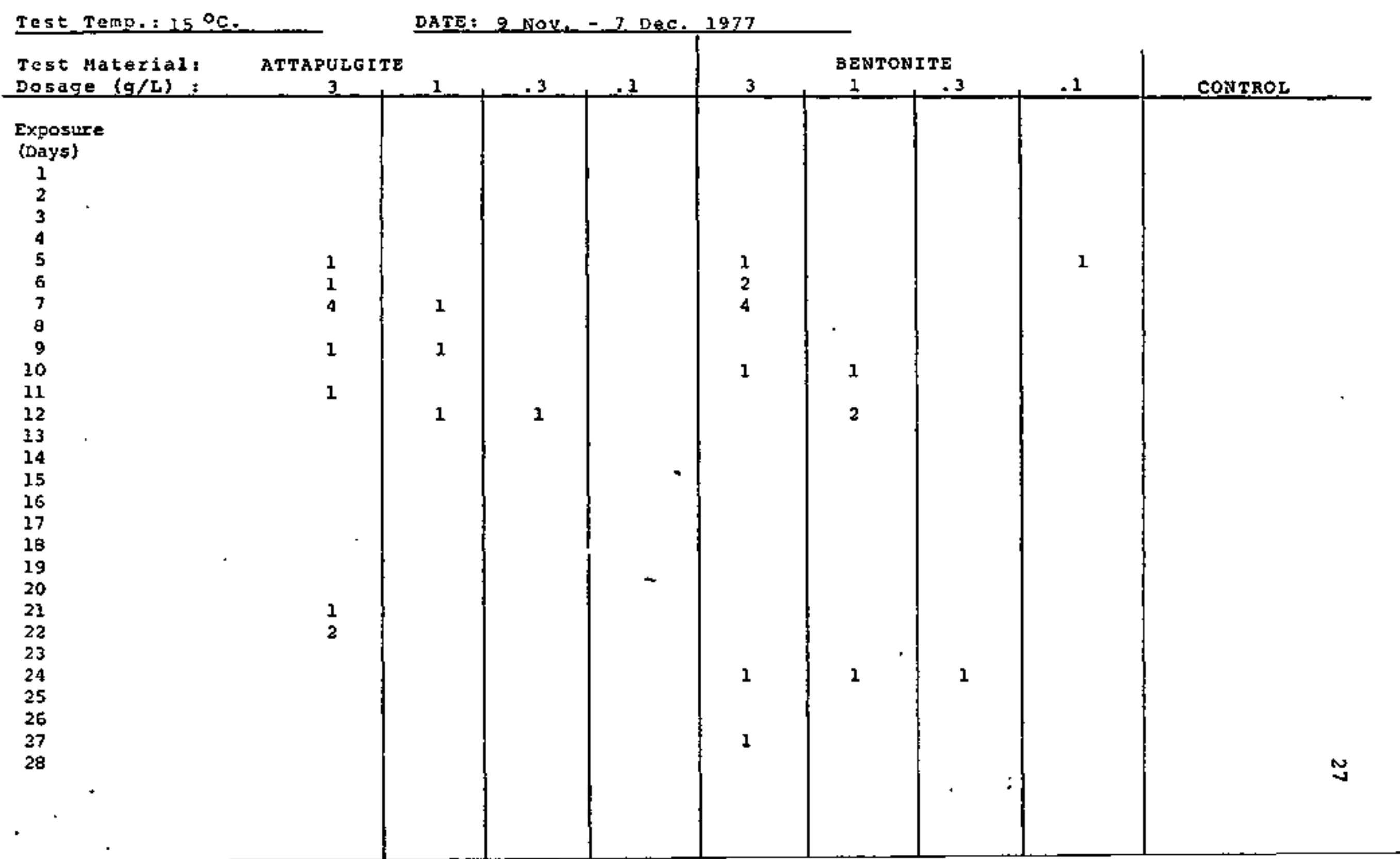


TABLE 9

MORTALITY. IN EXPERIMENT

( /8 in each tank)

Test Temp.: $50^{\circ} \mathrm{C}$.

DATEt 20 Jan. -6 Feb. 1978

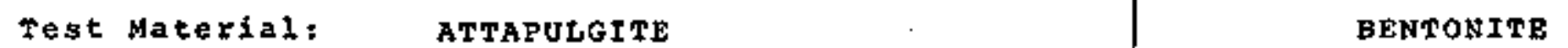

Dosage $(\mathrm{g} / \mathrm{L})$. ATTAPULGITE

\section{Exposure}

(Days)

1

2

4

5

6

7

9

10

11

22

13

14

15

16

17

18

19 Texmination of experiment becaluse of elpctrical gower loss kuring blifzaxa 20

21

22

23

24

25

26

27

28

2

1

1

1
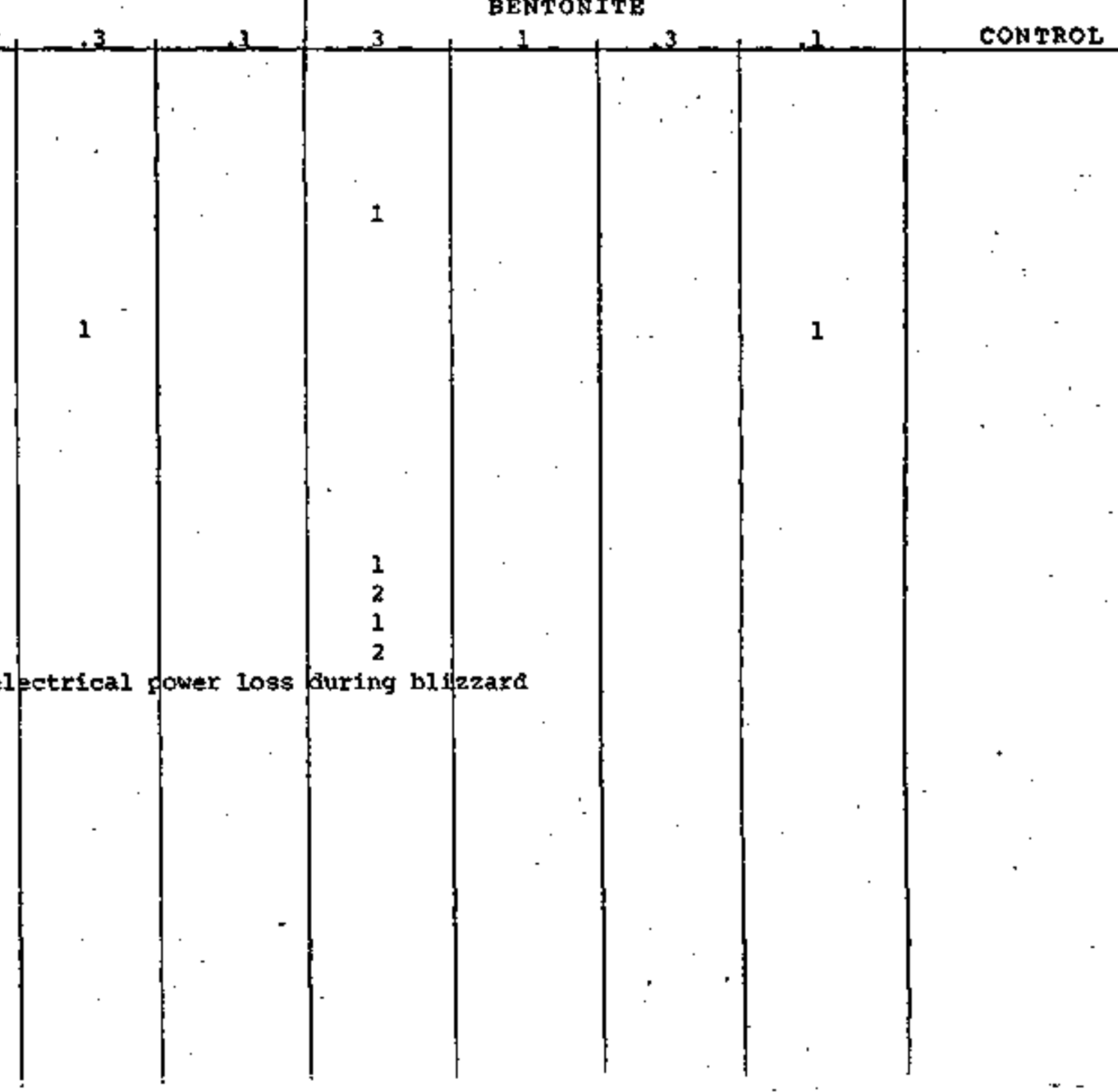


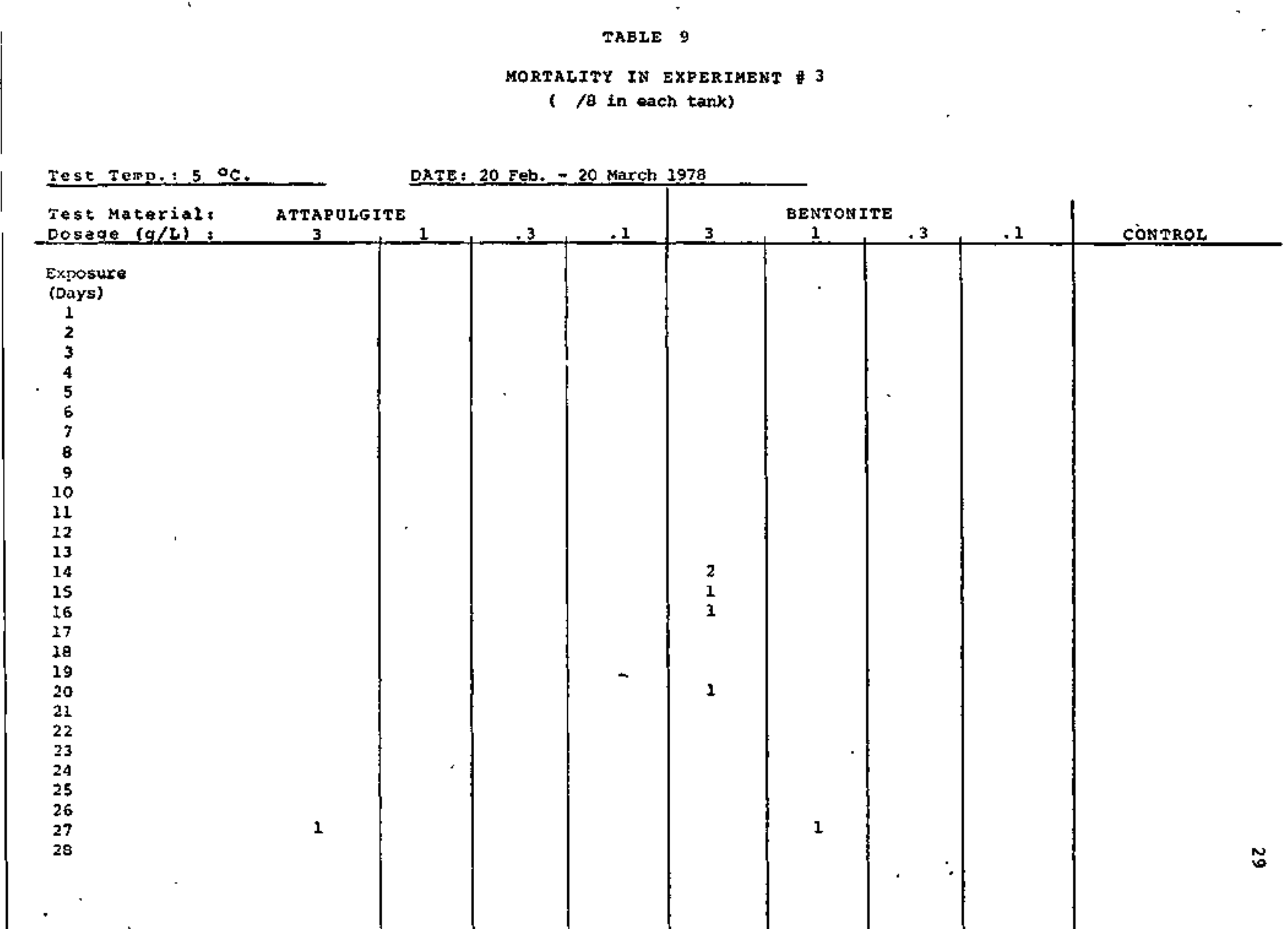


TABIE 10

NORTALITY IN EXPERIMENT \#4

( $/ 8$ in each $\tan k$ )

Test Temp.; 5 oc.

DATE; 27 March-26 April 1978

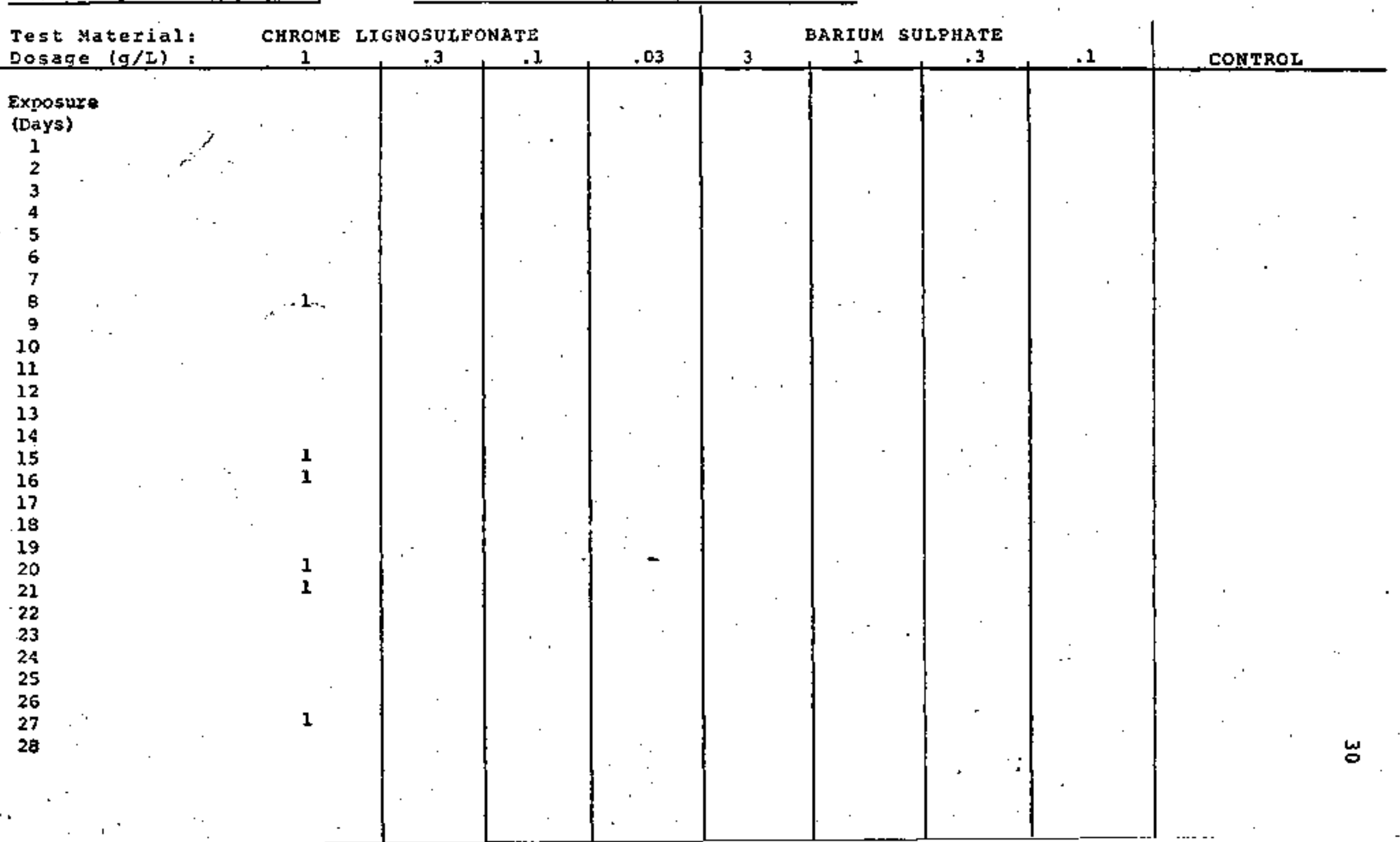


TABLE 11

MORTALITY IN EXPERIMENT

( $/ 8$ in each tank)

Test Tend: $15^{\circ} \mathrm{C}$.

DATE: 12 May - 9 June 1978

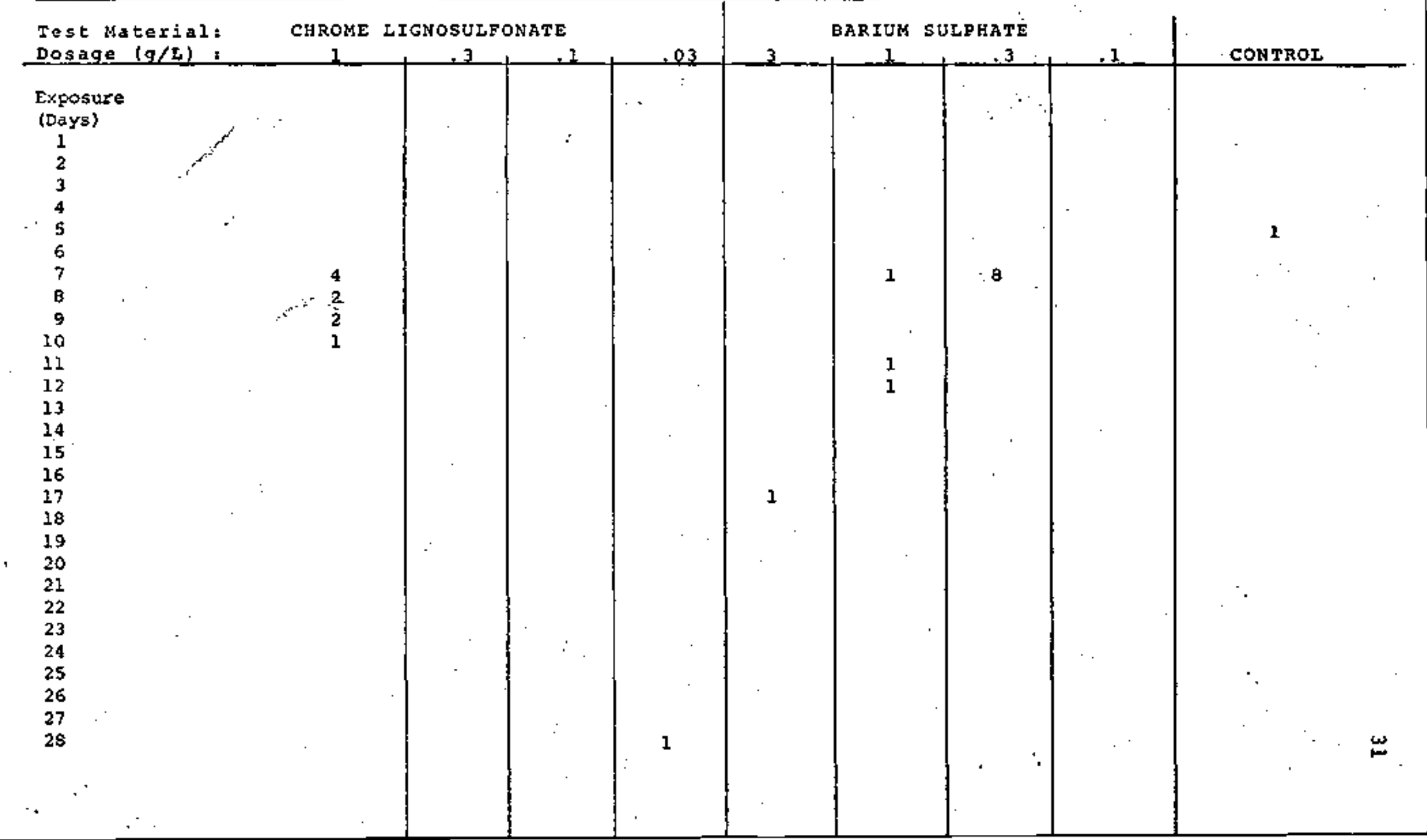


TABLE 12

MORTALITY IN EXPERIMENT \# 6

( $/ 8$ in each tank)

Test Temp.: $15^{\circ} \mathrm{C}$

DATE: 29 June-28 July 1978

Test Material: SYNTHETIC MUD WiTh ATTAPULGite

\section{Dosage $(g / L)$ :}

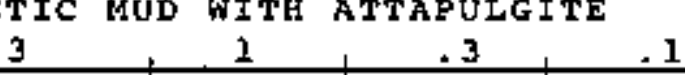

\section{Exposure}

(Days)

1

2

3

5

6

7

9

11

12

13

14

15

16

17

18

19

20

21.

22

23

24

25

26

27

28

5

1

1 3

SYNTHETIC MUD FITH BENTONITE

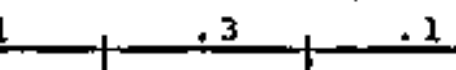

1

1

I

CONTROL 
TABLE 13

MORTALITY IN EXPERIMENT \# 7

( $/ 8$ in each tank)

Test Temp.: 50 . DATE: B Aug. - g sept. 1978

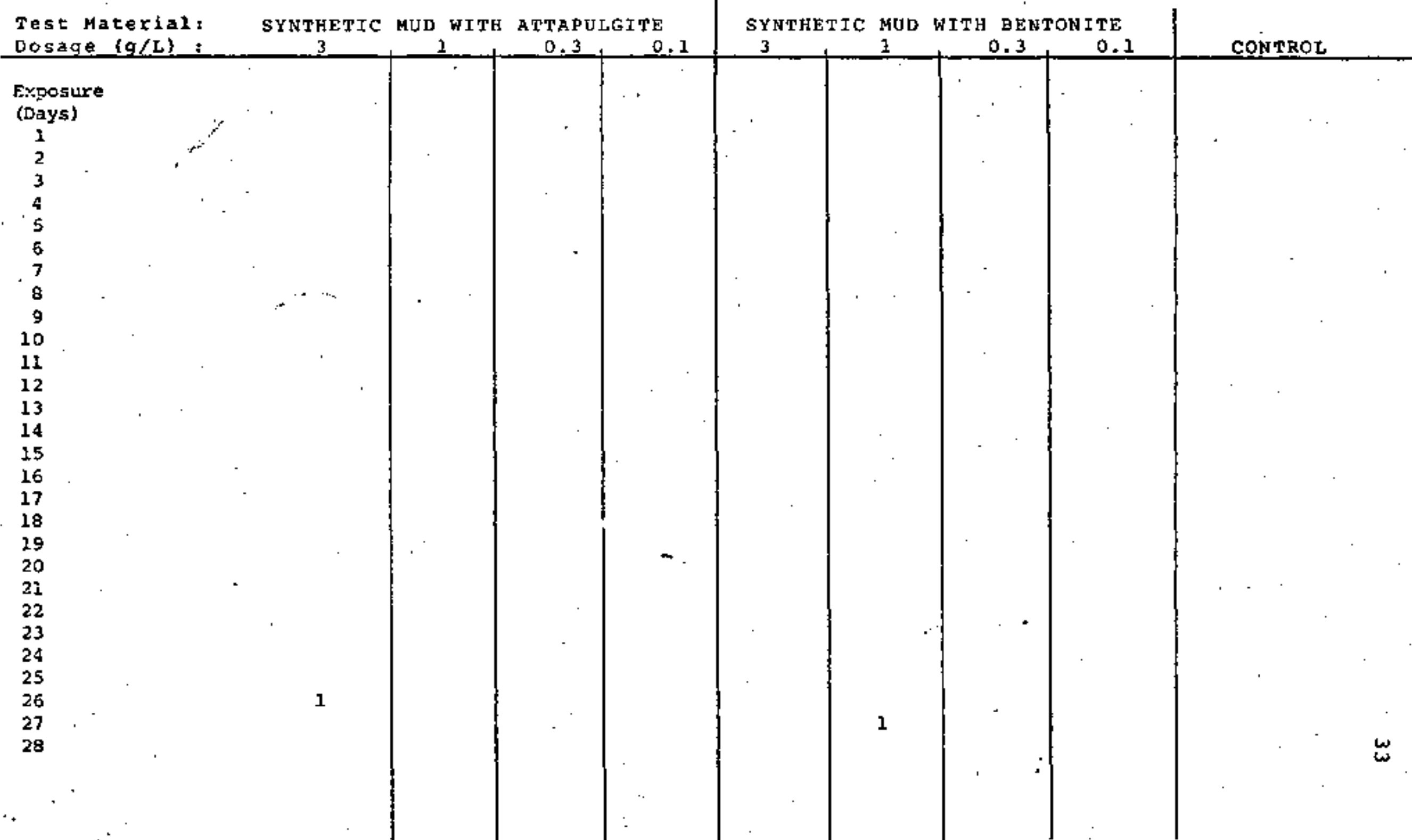




\section{TABLE 14}

MORTALITY RATES (8) DURING FIRST 10 DAYS OF EXPERIMENTS 1-3

\begin{tabular}{|c|c|c|c|}
\hline Exp. \# & $\begin{array}{l}\text { Test Material } \\
\text { semperature }\end{array}$ & Dosage & Mortality \\
\hline 1 & $\begin{array}{l}\text { Attapulgite } \\
25^{\circ} \mathrm{C} \\
\text { Bentonite } \\
\text { Control }\end{array}$ & $\begin{array}{l}3.0 \\
1.0 \\
0.3 \\
0.1 \\
3.0 \\
1.0 \\
0.3 \\
0.1 \\
0\end{array}$ & $\begin{array}{r}100 \\
25 \\
0 \\
0 \\
100 \\
12 \\
0 \\
12 \\
0\end{array}$ \\
\hline 2 & $\begin{array}{l}\text { Attapulgite } \\
5^{\circ} \mathrm{C} \\
\text { Bentonite } \\
\text { Control }\end{array}$ & $\begin{array}{l}3.0 \\
1.0 \\
0.3 \\
0.1 \\
3.0 \\
1.0 \\
0.3 \\
0.1 \\
0\end{array}$ & $\begin{array}{r}0 \\
12 \\
12 \\
0 \\
12 \\
0 \\
0 \\
12 \\
0\end{array}$ \\
\hline 3 & $\begin{array}{l}\text { Attapulgite } \\
5^{\circ} \mathrm{C} \\
\text { Bentonite }\end{array}$ & $\begin{array}{l}3.0 \\
1.0 \\
0.3 \\
0.1 \\
3.0 \\
1.0 \\
0.3 \\
0.1 \\
0\end{array}$ & $\begin{array}{l}0 \\
0 \\
0 \\
0 \\
0 \\
0 \\
0 \\
0 \\
0\end{array}$ \\
\hline
\end{tabular}


TABLE 15

MORTALITY RATES ( $\%$ ) DURING FIRST 10 DAYS OF EXPERIMENTS $4 \& 5$

Exp. \#

4

5

Control
Chrome Lignosulfonate $15^{\circ} \mathrm{C}$

Barium

Sulfate

Dosage

1.0

0.3

0.1

0.03

3.0

1.0

0.3

0,1

Control

1.0

0.3

0.1

0.03

3.0

1.0

0.3

0.1
Mortality

12

0

0

0

0

0

12

100

0

0

0

0

12

100

12

0 
TABLE 16

MORTALITY RATES (\%) DURING FIRST 10 DAYS OF EXPERIMENTS 6 \& 7

Exp. \#

6

7
Test Material

s Temperature

Synthetic Mud

with

Attapulgite

$15^{\circ} \mathrm{C}$

Synthetic Mud

with

Bentonite

Control

Synthetic Mud

with

Attapulgite

$5^{\circ} \mathrm{C}$

Synthetic Mud

with

Bentonite

Control
Dosage

3.0

1.0

0.3

0.1

3.0

1.0

0.3

0.1

Mortality

75

0

0

12

12

22

0

0

3.0

1.0

0.3

0.1

3.0

1.0

0.3

0.1

0

0

0 
TABIE $\quad 17$

RESULTS OF VISUAL OESERVATIONS FOR EXPERIMENT 6 $\left(15^{\circ} \mathrm{C}\right)$

Bentonite-based Synthetic Mud $(\mathrm{g} / \mathrm{L}\}$

$\begin{array}{lllll}3.0 & 1.0 & 0.3 & 0.1 & \text { Control }\end{array}$

EPseT

Yes/No Yes/No Yes/No Yes/No Yes/No

1. Gaping

2. Mantle disattached from lower shell

3. Adductor disattached from lower shell

4. Mantle disattached from upper shel1

5. Fdductor disattached from upper shell

6. Mantle response to probe

7. Adauctor response to probe

8. Smell

9. Mantle cavity clogged w/ "clay"

10. Mantle edge clogged w/ "clay"

11. Mantle surface w/ mucus

12. Gill clogged w/ "clay"

13. Gill frayed and tattered

14. Gill surface w/ mucus

15. Kidney texture

16. Kidney spotted

17. Kidney calor
$3 / 4$

$0 / 7$

$0 / 7$

$0 / 7$

$0 / 7$

$3 / 4$

$3 / 4$

$0 / 7$

$7 / 0$

$4 / 3$

$4 / 3$

$7 / 0$

$6 / 1$

$5 / 2$

$1 / 6$

$1 / 6$

$1 / 6$
$1 / 5$

$0 / 6$

$0 / 6$

$0 / 6$

$0 / 6$

$1 / 5$

$1 / 5$

$0 / 6$

$6 / 0$

$4 / 2$

$3 / 3$

$5 / 1$

$1 / 5$

$3 / 3$

$1 / 5$

$1 / 5$

$1 / 5$
$1 / 5$

$0 / 6$

$0 / 6$

$0 / 6$

$0 / 6$

$0 / 6$

$0 / 6$

$0 / 6$

$0 / 6$

4/2

$1 / 5$

$3 / 3$

$2 / 4$

$0 / 6$

$3 / 3$

$1 / 5$

$1 / 5$

$1 / 5$
$0 / 8$

$0 / 8$

$0 / 8$

$0 / 8$

$0 / 8$

$0 / 8$

$0 / 8$

$0 / B$

$0 / 8$

$0 / 8$

$0 / 8$

$0 / 8$

$0 / 8$

$0 / 8$

$0 / 8$

$0 / 8$

$0 / 8$ 
TABD 18

RESULTS OF VISUAL OBSERVATIONS FOR EXPERTHENT 6

Attapulgite-based synthetic Mud (

\section{EFFECT}

\section{Gapting}

2. Mentle disattached from lower shell

3. Adductor disattsched from lower shell

4. Mantle disattached from upper shell

5. Adductor disattached from upper ahell

6. Mantle response to probe

7. Adductor response to probe

8. Smell

9. Mantle cavity clogged w/ "clay"

10. Mantle edge clogged w/ "elay"

11. Mantle surface $w /$ mucus

12. Gill clogged w/ "clay"

13. Gill frayed and tattered

14. Gill surface $w /$ mucus

15. Kitiney texture

16. Kidney spotted

17. Xidney color

\section{0 \\ 2.0 \\ 0.3 \\ 0.1 \\ Control \\ Yes/No \\ $\underline{\text { Yes } / \text { No }}$ \\ Yes/No \\ Yes/No \\ Yes/No}

$9 / 0$

$4 / 3$

$1 / 5$

$0 / 6$

$0 / 8$

$5 / 3$

$0 / 8$

$3 / 4$

$1 / 5$

$0 / 7$

$1 / 6$

$0 / 6$

$0 / 6$

$0 / 9$

$4 / 4$

$2 / 5$

$1 / 6$

$0 / 8$

$0 / 7$

$0 / 6$

$0 / 6$

$0 / 8$

$0 / 8$

0

$2 / 5$

0

$5 / 1$

$5 / 1$

$6 / 0$

$6 / 0$

$1 / 7$

$2 / 5$

$1 / 6$

$0 / 6$

$8 / 0$

$8 / 0$

$3 / 4$

$3 / 4$

$1 / 6$

$3 / 4$

$1 / 5$

$1 / 5$

$0 / 6$

$0 / 6$

$0 / 6$

$3 / 5$
$1 / 5$

$8 / 0$
$8 / 0$

710

$7 / 0$

$0 / 6$

$0 / 6$

$0 / 6$

$B / 0$

$0 / 6$

$0 / 8$

$0 / 8$

$0 / 8$

$8 / 0$

$7 / 0$

$1 / 5$

$0 / 8$

$0 / 8$

$0 / 8$

$0 / 8$

$1 / 6$

$1 / 6$

$0 / 6$

$0 / 6$

$0 / 6$

$0 / 6$
$0 / 6$
$0 / 6$ 
TABEE 19

RESULTS OF VISUAL OBSERVATIONS FOR EXPERIMENT 7

$\left(5^{\circ} \mathrm{C}\right)$

Attapulgite-based synthetic Mud (g/L)

\section{EFEECT}

$\begin{array}{lllll}3.0 & 1.0 & 0.3 & 0.1 & \text { Control }\end{array}$

$\underline{\text { Yes/No }} \underline{\mathrm{Xes} / \mathrm{No}} \underline{\underline{\text { Yes/No}} \mathrm{Yes} / \mathrm{No} \text { Yes/No }}$

1. Gaping

2. Mantle disattached from lower sheIl

3. Adductor disattached from lower shell

4. Mantle disattacheo from upper shell

5. Aductor disattached from upper shell

6. Mantle response to probe

7. Adouctox response to probe

a. Smell

9. Martle cavity elogged w/ "elay"

10. Mantle edge clogged w/ "clay"

11. Nantle surface $w /$ mucus

12. Gill clogged w/ "clay"

13. Gill frayed and tatterea

14. Gill suzface w/ mucus

15. Kidney texture

16. Kicney spotted

17. Kidney color

\begin{tabular}{|c|c|c|c|c|c|c|}
\hline $0 / \theta$ & & $1 / 7$ & $0 / 8$ & $0 / 8$ & & $0 / \theta$ \\
\hline $0 / 8$ & & $1 / 7$ & $0 / 8$ & $0 / 8$ & & $0 / 8$ \\
\hline $0 / 8$ & & $0 / 8$ & $0 / 8$ & $0 / 8$ & $\therefore \quad \ldots$ & $0 / \theta$ \\
\hline $0 / 8$ & & $0 / 8$ & $0 / 8$ & $0 / 8$ & & $0 / 8$ \\
\hline $0 / \theta$ & & $0 / 8$ & $0 / 8$ & $0 / 8$ & & $0 / 8$ \\
\hline $8 / 0$ & & $7 / 1$ & $8 / 0$ & $8 / 0$ & & $8 / 0$ \\
\hline$B / 0$ & & $7 / 1$ & $8 / 0$ & $8 / 0$ & & $8 / 0$ \\
\hline$B / 0$ & & $7 / 1$ & $0 / 8$ & $0 / 8$ & & $0 / 8$ \\
\hline $5 / 3$ & & $2 / 6$ & $0 / 8$ & $0 / 8$ & & $0 / 8$ \\
\hline $5 / 3$ & & $2 / 6$ & $0 / 8$ & $0 / 8$ & & $0 / 8$ \\
\hline $5 / 3$ & & $2 / 6$ & $0 / \theta$ & $0 / 8$ & & $0 / 8$ \\
\hline $5 / 3$ & . & $2 / 6$ & $0 / 8$ & $0 / 8$ & & $0 / 8$ \\
\hline $0 / 8$ & & $2 / 6$ & $0 / 0$ & $0 / 8$ & & $0 / 8$ \\
\hline $6 / 2$ & . & $2 / 6$ & $0 / 8$ & $0 / 8$ & & $0 / 8$ \\
\hline $8 / 0$ & & $7 / 1$ & $8 / 0$ & $8 / 0$ & & $8 / 0$ \\
\hline $0 / \theta$ & & $7 / 1$ & $8 / 0$ & $8 / 0$ & & $0 / 8$ \\
\hline
\end{tabular}


TABLE 20

RESULTS OF VISUAL OBSERVATIONS FOR EXPERIMENT 7

$\left(5^{\circ} \mathrm{C}\right)$

Bentonite-based Synthetic wud $(\mathrm{g} / \mathrm{L})$

\section{EFEECT}

3. Gaping

2. Nantle disattached from lower sheil

3. Adductor disattached from lower shell

4. Mantle disattached from upper shell

5. Adductor disattached from upper she11

6. Mantle zesponse to probe

7. Adductor response to probe

8. Sme11

9. Mantle cavity clogged w/ "clay"

10. . Mantle edge clogged w/ "clay"

11. Mantle surface w/ mucus

12. G11l clogged w/ "clay"

13. Gill frayed and tattered

14. Gill surface $w /$ mucus

15. Kidney texture

16. Kidney spotted

27. Kidney color

\section{0}

3.0

Yes/No

$1 / 7$

$1 / 7$

$1 / 7$

$1 / 7$

$1 / 7$

$7 / 1$

$7 / 1$

$1 / 7$

$3 / 5$

$3 / 5$

$3 / 5$

$3 / 5$

$3 / 5$

$3 / 5$

$3 / 5$

$7 / 1$

$1 / 7$

Yes/No
0.3

0.1

Control

Yes/No

Yes/No

Yes/No

\begin{tabular}{|c|c|c|c|c|}
\hline $0 / 7$ & $0 / 7$ & $0 / 7$ & & $0 / \theta$ \\
\hline $0 / 7$ & $0 / 7$ & $0 / 7$ & & $0 / 8$ \\
\hline $0 / 7$ & $0 / 7$ & $0 / 7$ & $\therefore \ldots$ & $0 / 8$ \\
\hline $0 / 7$ & $0 / 7$ & $0 / 7$ & & $0 / \theta$ \\
\hline $0 / 7$ & $0 / 7$ & $0 / 7$ & & $0 / 8$ \\
\hline $7 / 0$ & $7 / 0$ & $7 / 0$ & & $8 / 0$ \\
\hline $7 / 0$ & $7 / 0$ & $7 / 0$ & & $8 / 0$ \\
\hline $0 / 7$ & $0 / 7$ & $0 / 7$ & & $0 / 8$ \\
\hline $0 / 7$ & $1 / 6$ & $0 / 7$ & & $0 / 8$ \\
\hline $0 / 7$ & $1 / 6$ & $0 / 7$ & & $0 / 8$ \\
\hline $0 / 7$ & $1 / 6$ & $0 / 7$ & & $0 / 8$ \\
\hline $0 / 7$ & $1 / 6$ & $0 / 7$ & & $0 / 8$ \\
\hline $0 / 7$ & $3 / 6$ & $0 / 7$ & & $0 / 8$ \\
\hline $0 / 7$ & $1 / 6$ & $0 / 7$ & & $0 / 8$ \\
\hline $0 / 7$ & $1 / 6$ & $0 / 7$ & & $0 / 8$ \\
\hline $7 / 0$ & $6 / 1$ & $7 / 0$ & & $B / 0$ \\
\hline $0 / 7$ & $1 / 6$ & $0 / 7$ & & $0 / 8$ \\
\hline
\end{tabular}




\section{Filtration Experiments}

The results for 3 clearing rate studies are given in Tables 21 to 23 . Table 21 shows the effects on clearing rate in placopecten magellanicus held in attapulgite and bentonite. The animals exposed to attapulgite showed clearing rates greater than those of the controls throughout the exposure range. After exposure to bentonite, clearing rates increased for the lowest dosage, fell below controls at $0.3 \mathrm{~g} / \mathrm{L}$, and rose above control values for the remainder of the concentration range. Attapulgite at $15^{\circ} \mathrm{C}$ appears to induce higher clearing rates than does bentonite. Higher clearing rates require a greater expenditure of energy which over the long term would be more detrimental to the maintenance, growth, and reproductive capacity of the sea scallops.

Tables 22 and 23 show the effects of exposure to chrome lignosulfonate and barium sulfate on scallops held at $15^{\circ} \mathrm{C}$ and $5^{\circ} \mathrm{C}$. At $15^{\circ} \mathrm{C}$ in chrome lignosulfonate, the clearing rate for scallops at $0.03 \mathrm{~g} / \mathrm{L}$ is $12 \mathrm{ml} / \mathrm{g} / \mathrm{hr}$, rising to $21 \mathrm{ml} / \mathrm{g} / \mathrm{hr}$ and falling to $9.5 \mathrm{ml} / \mathrm{g} / \mathrm{hr}$. At $5^{\circ} \mathrm{C}$ all rates are lower, but the same pattern may be observed with clearing rates falling substantially at the highest concentration $(1.0 \mathrm{~g} / \mathrm{L})$. The concentration at which the greatest fall in clearing rate occurs is more than three times greater at $5^{\circ} \mathrm{C}$ than at $15^{\circ} \mathrm{C}(0.3$ versus $1.0 \mathrm{~g} / \mathrm{L})$. Clearing rates of animals exposed to barium sulfate at $15^{\circ} \mathrm{C}$ were greater than for the controls at low dosages, but fell at the highest concentrations. At $5^{\circ} \mathrm{C}$, there is a reduction in clearing rates 
at $0.1 \mathrm{~g} / \mathrm{L}$, a rise at intermediate concentrations, and a fall below control levels at $3.0 \mathrm{~g} / \mathrm{L}$.

The data indicate that at $15^{\circ} \mathrm{C}$, there may be compensatory depressions in clearing rates as the animals are exposed to low levels of drilling mud components (e.g., $0.03 \mathrm{~g} / \mathrm{L}$ chrome lignosulfonate). The compensation may indicate an effort by the organism to reduce clearing rates in an attempt to limit the amount of contact it has with the mud component. At intermediate concentrations this strategy may not be tenable and so clearing activity accelerates in order to maintain clean respiratory surfaces. A reduction in clearing rates at the highest concentrations of CLS and barium sulfate may be either an adjustment to limit energy expenditure in order to save biochemical stores, or it may be an indication that the animal has exhausted its most accessible energy stores and is forced to continue clearing only slowly with less accessible energy sources. To better understand the significance of these responses, metabolic studies such as measurements of oxygen uptake or the utilization of carbohydrate and lipid stores should be carried out. Such work would help understand the strategies adopted by animals exposed to various levels of mud to mobilize these energy stores and cope with the particulate perturbation. 
TABLE 21

P. magellanicus clearing Rates at $15^{\circ} \mathrm{C}$

Test

Material

Attapulgite

Bentonite

Control
Dosage

(g/L)

0.1

0.3

1.0

3.0

0.1

0.3

1.0

3.0
Clearing Rate (ml cleared per gram dry weight per hr)

$35.1 \pm 0.9$

$24.5 \pm 6.8$

$36.0 \pm 7.9$

$30.5 \pm 2.8$

$27.9 \pm 2$

$14.9 \pm 0.7$

$32.3 \pm 6.4$

$24.8 \pm 9.2$

$17.2 \pm 2.7$ 
TABLE 22

P. MAGELLANICUS CLEARING RATES AT $15^{\circ} \mathrm{C}$

Test

Material

\section{Chrome}

Lignosulfonate

Barite

Control
Clearing Rate

Dosage

$(\mathrm{g} / \mathrm{L}\rangle$

(ml cleared per gram

dry weight per hr)

$$
\begin{array}{r}
0.03 \\
0.10 \\
0.30
\end{array}
$$

0.10

1.00

3.00

$$
\begin{array}{r}
12.0 \pm 0.6 \\
21.0 \pm 1.0 \\
9.5 \pm 1.5
\end{array}
$$

$23.5 \pm 3.4$

$16,0 \pm 2,0$

$14.5 \pm 0.8$

$18.0 \pm 4.0$ 
TABLE 23

P. Magellanicus CLEARING RATES AT $5^{\circ} \mathrm{C}$

Test

Material

Chrome

Lignosulfonate

Barite

Control.
Dosage

$(g / L)$

0.03

0.10

0.30

1.00

0.10

0.30

1.00

3.00

Clearing Rate (mi cleared per gram dry weight per hr)
$4.5 \pm 1.1$

$7.8 \pm 2.1$

$7.9 \pm 0.7$

$5.7 \pm 1.5$

$4.5 \pm 0.9$

. $14.5 \pm 4.7$

$12.5 \pm 0.4$

$8.0 \pm 1.4$

$9.5 \pm 0.5$ 
D. Histological Observations

To further assess the effects of exposure to the drilling mud components and synthetic mud mixtuxes, histological analysis of selected tissues have been carried out. The results reported describe cellulax changes in several regions of the

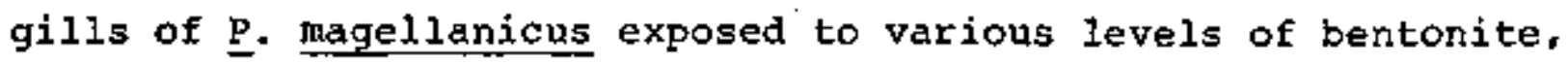
attapulgite, barium sulfate and cLs.

Because they function in intimate contact with the external environment, the gills are susceptible to physical or chemical damage and to surface obstruction by high concentrations of particulate matter in the environment. Such damage and clumping or occlusion of the respiratory feeding surfaces would cause a major impairment to the function of these vital organs. With impaired function, the animals so afflicted could show reduced growth rates, reduced reproductive capacity, or increased mortality rates leading to a diminishing population.

Bivalve molluscs have two gills suspended close to the body at either side of the mantle cavity. Each gill is subdivided into two lamellae composed of minute parallel filaments. The filaments are tubular, blood-carrying structures, the walls of which are 1 cell-layer thick. The fronatal surfaces of the filaments (thus, the gills) which first contact the inflowing water current bear ciliated cells which produce the water current and assist in retaining particles. To their side are the specialized frontolateral cilia which also trap particles. Mucus goblet cells are occasionally found on the frontal and frontolateral 
surfaces under normal conditions, but only very rarely on the lateral and abfrontal aspects of the filaments. The cells produce and discharge mucous materials which form the mucus net to retain particles in the respiratory current. The results from experimients 1-5 (Tables 24 to 27) show that as the concentration of particulate matter is increased, the incidence of mucus cells in the Erontal area decreases. In the Iaterofrontal area, however, there seems to be a lower threshold concentration, $0.1 \mathrm{~g} / \mathrm{L}$ attapulgite and $0.3 \mathrm{~g} / \mathrm{L}$ bentonite, at which the frontolateral mucus cell occurrence resembles or surpasses that of controls. At higher doses the occurrence of mucus cells declines. The results for lateral and abfrontal mucus cell occurrence show an increase in mucus cell proliferation immediately upon addition of particles. Tissue structure observations reveal that as concentrations of particulate matter increase to $0.3 \mathrm{~g} / \mathrm{L}$ attapulgite and $1.0 \mathrm{~g} / \mathrm{L}$ bentonite, necrotic changes occur. The tissue changes are characterized by the placement of cell Iayers and broken cell membranes. These manifestations of dose impact are most outstanding in $1.0-3.0 \mathrm{~g} / \mathrm{L}$ attapulgite; the effects shown for $1.0 \mathrm{~g} / \mathrm{L}$ attapulgite axe not approached with bentonite until it is used at a concentration of $3.0 \mathrm{~g} / \mathrm{L}$.

The results of the experiments to determine concentration effects of attapulgite and bentonite at $15^{\circ} \mathrm{C}$ are given in Tables 24 and 25 . They show that at $0.1 \mathrm{~g} / \mathrm{L}$, the bentoniteexposed samples had reduced incidence of mucus cells, while at $1.0 \mathrm{~g} / \mathrm{h}$ frontal incidence was only slightly lower than controls, 
TABLE 24

9. MAGELLANICUS - MUCUS CELL OCCURRENCE IN VARIOUS ANATOMICAL AREAS OF gILLS OF ANTMALS EXPOSED TO BENTONITE

$15^{\circ} \mathrm{C}$

Control

Bentonite $3.0 \mathrm{ppt}$

Bentonite 1.0 ppt

Bentonite $0.1 \mathrm{ppt}$

$\underline{50}$

Control

Bentonite $3.0 \mathrm{ppt}$

Bentonite

$1.0 \mathrm{ppt}$

Bentonite

0.3 ppt

\section{Frontal}

Mean SD

$6.6 \pm 1.1$

- $\quad$

$5.6 \pm 1.1$.

$4.4 \pm 1.1$

10. \pm 2 .

10. \pm 1.4

$2.0 \pm 1.1$

10. \pm 2 .

$.1 \pm 1.7$

$0.30 \pm 0.38$

$0.04 \pm 0.01$

$0.30 \pm 0.61$

Aberontal

Mean $\underline{\mathrm{SD}}$

$0.12 \pm 0.28$

$0.12 \pm 0.35$

$1.3 \pm 0.7$

$0.10 \pm 0.2 \mathrm{~B}$

$4.8 \pm 1.1$

$7.1 \pm 1.2$

$0.04 \pm 0.01$

$0.04 \pm 0.01$

$0.04 \pm 0.01$

$0.5 \pm 0.7$

$0.16 \pm 0.54$

$0.04 \pm 0.01$

$0.40 \pm 0.38$

$1.2 \pm 0.4$

$1.1 \pm 0.7$

$8.3 \pm 1.3$

$0.60 \pm 0.54$

$0.24 \pm 0.37$ 
TABIE 25 :

P. MAGELLANICUS - MUCUS CELL OCCURRENCE IN VARIOUS ANATOMTCAL AREAS OF GILLS OF ANIMALS EXPOSED TO ATTAPULGITE

$15^{\circ} \mathrm{C}$

Control

Attapulgite 3.0 ppt

\section{Attapulgite} 1.0 ppt

$5^{\circ} \mathrm{C}$

Control

Attapulgite $3.0 \mathrm{ppt}$

Attapulgite 1.0 ppt

Attapulgite 0.3 ppt

Attapulgi te 0.1 ppt

\section{Fronta:}

Mean SD

$6.6 \pm 1.1$

$4.8 \pm 1.1$

$0.28 \pm 0.47$

$1.5 \pm 0.8$

$2.8 \pm 1.2$

\section{Frontolateral}

Mean SD

10. \pm 1 .

$7.1 \pm 1.2$

$1.4 \pm 0.7$

$5.3 \pm 1.5$
$3.0 \pm 1.4$

\section{Mean SD}

$0.04 \pm 0.01$

$0.28 \pm 0.38$

$0.04 \pm 0.01$

$0.040 \pm 0.01$

$0.8 \pm 0.7$

$0.44 \pm 0.45$

\section{Abfronta1}

Mean SD

$0.12 \pm 0.28$

0.38

$0.1 \pm 0.8$

$0.20 \pm 0.45$

$0.28 . \pm 0.38$

$0.28 \pm 0.52$ 
P. MAGELIANICUS - MUCUS CELL OCCURRENCE IN VARIOUS ANATOMICAL AREAS OF GILLS OF ANIMALS EXPOSED TO CHROME LIGNOSULFONATE

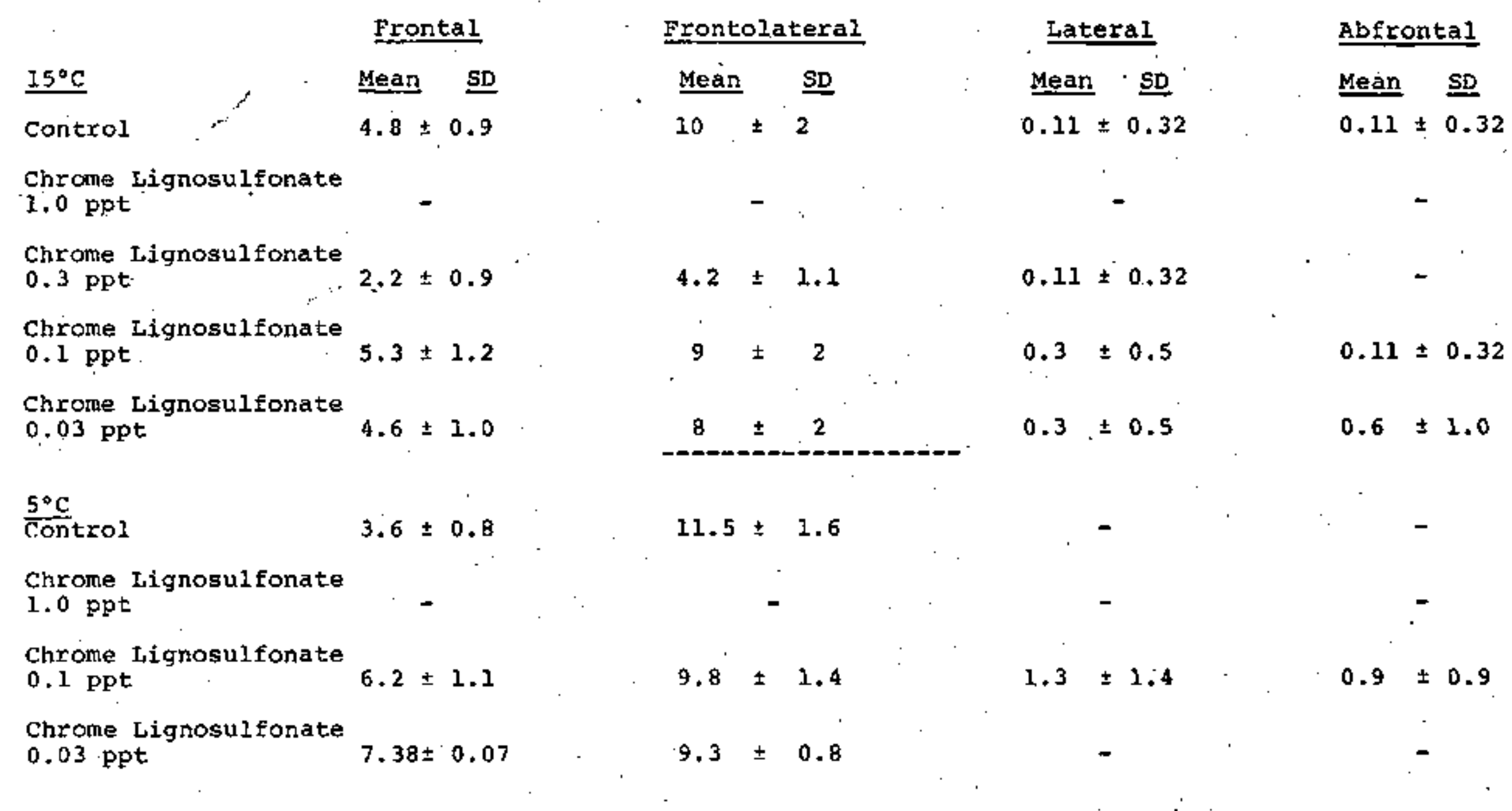


P. MAgELLANICUS - MUCUS CELL OCCURRENCE IN VARIOUS ANATOMICAL AREAS OF GILLS OF ANIMALS EXPOSED TO BARIUM SULFATE

\section{$\underline{15^{\circ} \mathrm{C}}$}

Control

Barium sulfate $3.0 \mathrm{ppt}$

Barium sulfate 1.0 ppt

Barium sulfate 0.3 ppt

Barium sulfate

0.1 ppt

$5^{\circ} \mathrm{C}$

Control

Barium sulfate 3.0 ppt

Barium sulfate

$1.0 \mathrm{ppt}$

Barium sulfate 0.3 ppt

Barium suifate

$0.1 \mathrm{ppt}$

\section{Frontal}

Mean SD

$4.81 \pm 0.939$

$4.3 \pm 0.8$

$3.7 \pm 0.8$

$6.7 \pm 1.4$

$4.0 \pm 0.9$

$3.5 \pm 0.8$

$2.0 \pm 1.1$

$2.2 \pm 1.2$

$4.2 \pm 1.2$

$3.1 \pm 0.7$

\section{Frontolateral}

Mean $S D$

$10 \pm 2$

$13 \pm 1$

$6 \quad \pm 2$

$9 \pm 2$

7

$\pm 2$

$11.8 \pm 1.6$

$6.2 \pm 1.7$

$6.4 \pm 1.5$

$6.0 \pm 1.6$

$0.9 \pm 1.6$

$0.4 \pm 0.9$

$0.3 \pm 0.7$

$8.2 \pm 1.4$
Abfrontal

Mean SD

$0.11 \pm 0.32$

$2.9 \pm 1.0$

$1.6 \pm 1.1$

$2.6 \pm 1.2$

$0.9 \pm 1.1$

$0.5 \pm 0.9$ 
while frontolaterals had elevated numbers in comparison to controls. The lateral cells proliferated at $0.1 \mathrm{~g} / \mathrm{L}$ bentonite and to a very large 6.16 in $1.0 \mathrm{~g} / \mathrm{L}$ bentonite; at $3.0 \mathrm{~g} / \mathrm{L}$ bentonite, the lateral incidence had dropped. The findings for abfrontal cells was nearly as for lateral aspects; the lateral and the abfrontal occurrences increased. At $3.0 \mathrm{~g} / \mathrm{L}$ attapulgite, the sections consisted of completely disrupted cells, with only occasional cell ghosts or broken membranes visible through the microscope.

E. Trace Elements in Scallop Tissues

The tissues from organisms exposed to Q-Broxin at $5^{\circ} \mathrm{C}$ and $15^{\circ} \mathrm{C}$ and to the bentonite-based synthetic mud at $15^{\circ} \mathrm{C}$ have been analyzed for $\mathrm{Cr}$ and several other elements. The results of these measurements are contained in Tables 28 and 29 .

The data in Table 28 show that scallops exposed to solutions of Q-Broxin accumulate chromium. Elevated levels of the element were found in the fast and slow muscles as well as in those organs exposed directly to the Q-Broxin solutions; the gill, mantle and digestive gland.

Concentrations of the element in muscle tissues indicates that the animal is assimilating the element in addition to pumping it through its digestive system.

Organisms exposed to a mixture of mud components including Q-Broxin also showed an increase in cr levels in several target tissues including the fast muscle and kidney. These results seem to indicate that, despite being associated with a fine-grained 
TABLE 28

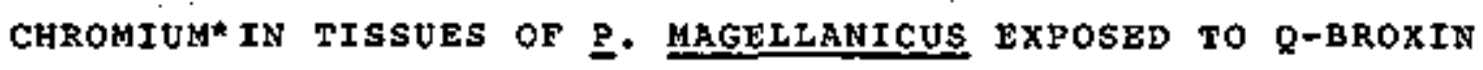

\begin{tabular}{|c|c|c|c|c|c|c|c|}
\hline Terne. & $\begin{array}{l}\text { Q-Broxin } \\
\text { Loading } \\
\text { (g/L) }\end{array}$ & $\begin{array}{l}\text { Dlgestive } \\
\text { Gland } \\
\text { (mg/g) }\end{array}$ & $\begin{array}{c}\text { Fast } \\
\text { Muscle } \\
(\mu \mathrm{g} / \mathrm{g})\end{array}$ & $\begin{array}{c}\text { Gill } \\
\text { (mog/g) }\end{array}$ & $\begin{array}{l}\text { Kidney } \\
\underline{\mu} g / g) \\
\end{array}$ & $\begin{array}{l}\text { Mantle } \\
(\mu g / g)\end{array}$ & $\begin{array}{c}\text { slow } \\
\text { muscle }\end{array}$ \\
\hline \multirow[t]{4}{*}{$5^{\circ} \mathrm{C}$} & 1.0 & 0.19 & 57 & $5.6=$ & 27 & 84 & 15 \\
\hline & 0.3 & 0.29 & 7 & 0.22 & 23 & 25 & 3.2 \\
\hline & 0.1 & 0.10 & 5 & 0.15 & 11 & 10 & 2.0 \\
\hline & 0.03 & 0.05 & 1 & 0.16 & 11 & 11 & 1.8 \\
\hline \multirow[t]{4}{*}{$15^{\circ} \mathrm{c}$} & $1.0^{* *}$ & 0.18 & $\mathbf{B}$ & 0.11 & 24 & 32 & 2.5 \\
\hline & 0.3 & 0.42 & 7 & 0.34 & 18 & 27 & 6.6 \\
\hline & 0.1 & $0 . \hat{3}$ & 3 & 0.22 & 46 & 33 & 3.5 \\
\hline & 0.03 & 0.02 & 2 & 0.14 & 43 & 19 & 0.4 \\
\hline
\end{tabular}

- Concentration values in Tables 28 and 29 are based on ary tissue weights.

** Data are for tissues blended from seven organisms, all of which died within 1 week of the start of the test. 
TABLE 29

TRACE ELEMENTS IN TISSUES OF P. MAGELLANICUS EXPOSED TO BENTONITE-BASED SYNTHETIC WUD AT $15^{\circ} \mathrm{C}$

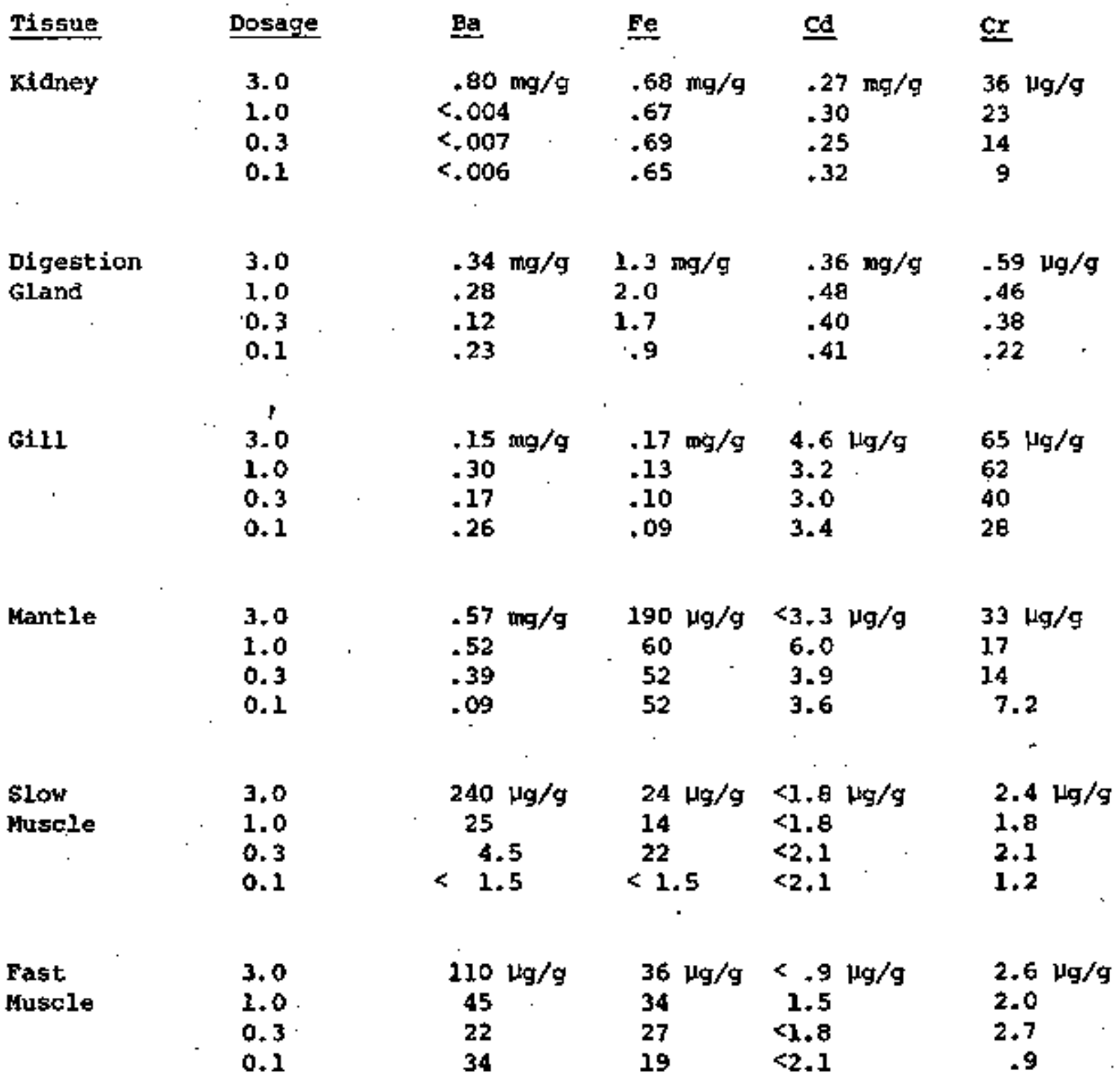


particulate phase, $\mathrm{Cr}$ is still assintilated by the scallop. $\mathrm{Ba}, \mathrm{Fe}$ and $\mathrm{Cd}$ were also measured in the latter set of tissues: $\mathrm{Ba}$ was present in the test material as $\mathrm{BaSO}_{4}$ : QBroxin is 1 i $\mathrm{Fe}$, and cd was believed to be a possible contaminant in the mixture. The data in Table 29 inaicate that $C d$ is not enriched in the target tissues as a result of exposure to the mixed mud. Both $\mathrm{Ba}$ and $\mathrm{Fe}$ were assimilated as indicated by the elevated levels of these elements in the muscles and, in the case of $\mathrm{Ba}$, in the kidneys of animals exposed to the higher dosages of the synthetic mud. The lack of change in $\mathrm{Fe}$ concentrations in kidney tissues with increased dosage rates may mean that the animal does not view this essential element as an undesirable constitutent which it must purge from its body, even when it is present at elevated levels. 


\section{vi: CONCLUSIONS}

At suspended solid loadings approaching $3 \mathrm{~g} / \mathrm{L}$, drilling muds, especially those containing attapulgite as the principal

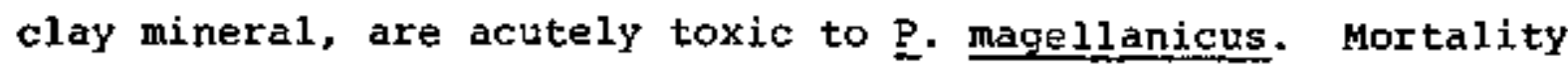
was significantly higher under summer conditions: $15^{\circ} \mathrm{C}$ water and relatively high food loading. The reason for the greater toxicity of attapulgite versus bentonite, efther alone or in mud mixtures, was not established. There exist considerable differences in primary structure, degree of hydration andor cation exchange capacity between the two minerals.

visual inspection proved to be a surprisingly precise index of environmental stress. The most useful types of response were muscular attachment to the shell, condition of the kidney, presence of clay in various organs, and conditions of the gills. The control samples and those exposed to $0.1 \mathrm{~g}$ of synthetic mud/L were usually similar; however, the appearance of animals exposed to higher dosages changed significantly with dosage.

Filtration rate has not been the precise and predictable indicator of stress that had been hoped at the start of the study. In most experiments, low levels of mud components apparently pronoted filtration, perhaps as the animals attempted to clear particulate matter from their gills. At the highest loadings animals under the most stress exhibited a decrease in clearing rate as their energy stores were depleted. However, the significance in these trends in individual experiments is often doubtful because of the relatively large uncertainties in the 
measurements. More precise measurements would require more test organisms than are now being used and more uniformity in their size.

Another effect of exposure to drilling mud components is a change in mucus cell proliferation and mucus production on the gills. With increasing concentrations of mud components, mucus is profuced to assist in cleaning the gill surfaces, transporting particles, and producing pseudofeces. Increased mucus production places demands on the metabolism and energy reserves of the animals. The energy stores held by the animals for normal maintenance, growth and reproduction are then consumed under the stress of the particulates exposed. The utilization; of these energy reserves for the immediate survival of the individual may have long term detrimental effects on. reproduction and recruitment.

Organisms assimilate some of the elements present at high concentrations in drilling muds: Fe, Cr and Ba. The extent to which these elements are taken up appears to be a function of the total elemental loading, which is mostly in a particulate form. Presumably dissolved $\mathrm{Fe}, \mathrm{Cr}$ and $\mathrm{Ba}$ concentrations are not a direct function of mud loading -- a presunption that is being checked by analyses of test tank seawater as this report is being written. Of these three elements, only Fe is not found at elevated levels in the kidneys of animals exposed to the highest loadings of synthetic mud, indicating the Fe does appear to the organisns to be an undesirable element. The length of 
time during which the $\mathrm{Cr}$ and $\mathrm{Ba}$ content of the kidney remains high after exposure to drilling mua will soon be measured in a series of depuration experimerts. 
VII. REFERENCES

Ansel1, A. D. and P. Sivadas. 1973. J. Exp. Mar. Biol.

Ecol. $13,229$.

Jorgensen, C. B. 1943. Acta Physiol. Scand. S, 297.

McAtee, J. L. and N. R. Smith.' 1969, J. Colloid and

Interface Sci., 29(3), 389.

Stone, R. L., R, E. Palmer and W. T. Chen. 1974, Rep. to

U.S. Army Corps of Engineers, New England Div., Oct. 15,

$46 \mathrm{Pp}$.

Willensen, J.' 1952. Arch. Neerl. 2001., 10, 153. 
VIII. APPENDIX 
The Suspended Sediments Sedwater Aquariun System

The suspended sedjuents seawater aquarium system consists of four basic components (Fig. Al):

(1) a seawater treatment facility,

(2) an aquarium tank-disperser assembly (seawater),

(3) a temperature control/regulator assembly (fresh whter,

(4) a thermal exchanger unit at which 2 and 3 interface.

In addition to the aquarium șystem and seawater treatment facility a unit has been buflt in which thick sediment-seawater slurries may be mixed. The job is a particularly dirty one, so it will be perfomed outside the laboratory area, the mixed slurries being punped to the laboratory for storage and eventual use.

Seawater Treatment

The laboratory system was designed to study turbidity effects on marine animals. Water treatment, for our purposes, means removing naturally occurring purticulates from the general laboratory supply and killing the bacteria in the filtered stream. The intent of these operations is to provide particulate-free water for making up experimental turbidity loads and insuring a low rate of water-quality degradation by bacteria during an experiment.

Aguarium-Disperser Assembly

The part of the installation in which marine organisms are exposed to various experimental turbidity loads is the aquarium-disperser assembly. It consists of 16 helmet-shaped fiberglass aquarium tanks (a 


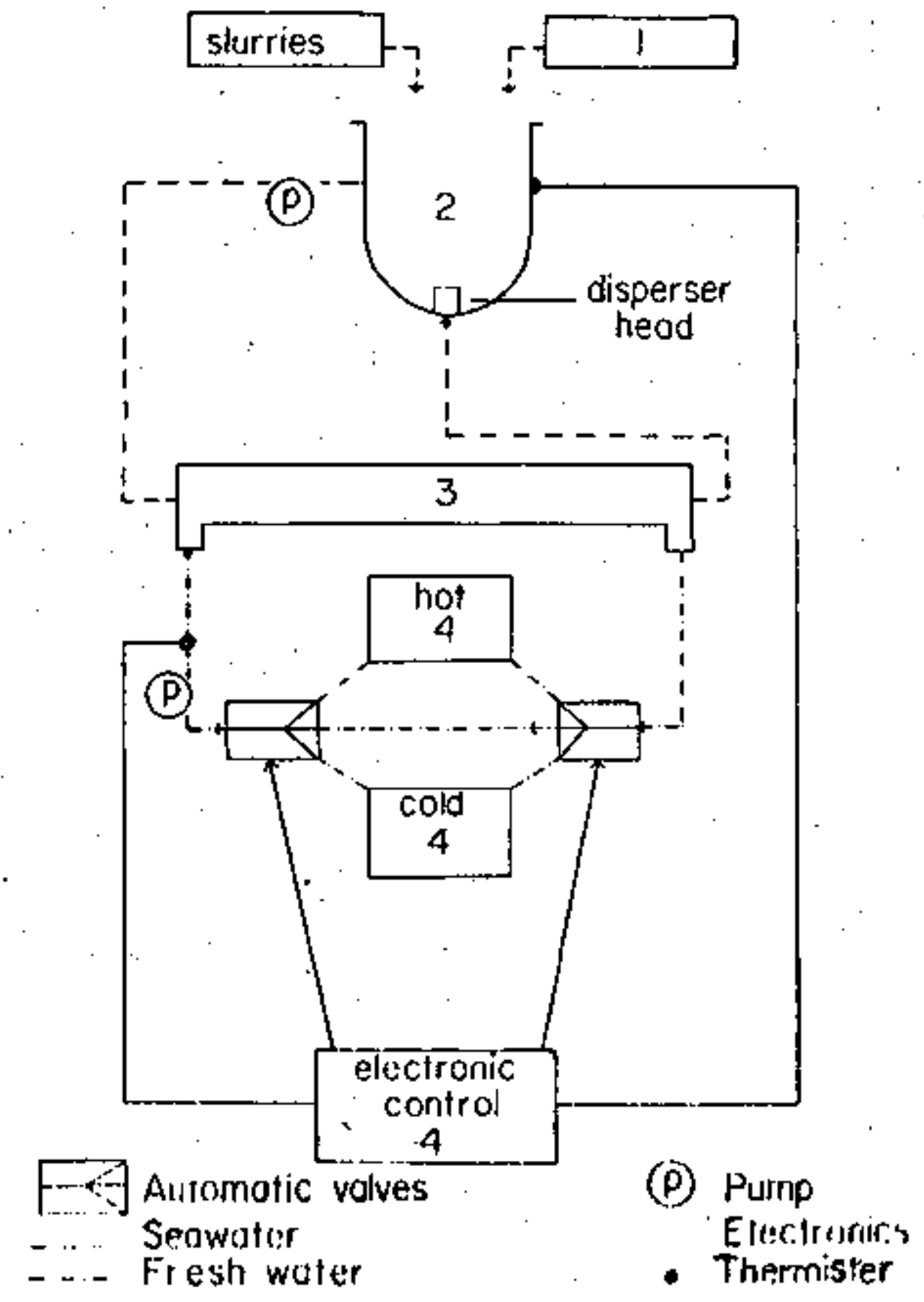

Fig. Al. Diagram of the subpended sedinicitg seawnter aquarlan system: 1, treeted seawater supply; 2, aquariumdisperser assembly; 3 , thermal exchanger; 4, eltctronic temperature control-regulator. 
single unit is pictured in Fig. 1). A disperser head is integral to each of the aquaria. In addition, a pump is associated with each aquarfum-disperser assembly. Each of the 16 assemblies is a discrete aquarium unit containing its own turbidity load. No intermingling of the contents of neighboring aquaria can take pldce.

The pump in each assembly serves a dual purpose. It strips seawater-slurry from the aquarium and returns the mixture to the tank by way of a thermal exchanger and the disperser head. In this manner the pump not only maintains a homogeneous suspension of particulate matter whin the aquarium but also creates an interface with the temperature control regulation circuit.

Thermal Exchanger

The thermal exchanger is of a simple tube-in-shell construction. The fluid contents of the aquariun-disperser assembijes pass down tubes which are surrounded by temperature-regulated fresh water flowing in the shell. During the passage, the seawater-slurries attain the temperature of the exchanger water.

\section{Ienperature Control/Regulator}

The temperature of the fresh water flowing through the therinal exchanger (and, therefore, in the seawater-slurries in the aquaria) is governed by the temperature control/regulator assembly. It consists of reservoirs for hot- and cold-tempered fresh water, an electronic control device and automatic denand valve units.

The heart of the system is the control device; in essence a small solidstate logic syster. It acts upon signals from the exchanger supply circuit 